\title{
34. TERRIGENOUS AND MARINE LIPIDS IN AMAZON FAN SEDIMENTS: IMPLICATIONS FOR SEDIMENTOLOGICAL RECONSTRUCTIONS ${ }^{1}$
}

\author{
Kai-Uwe Hinrichs ${ }^{2}$ and Jürgen Rullkötter ${ }^{2}$
}

\begin{abstract}
Preliminary lipid analyses of Amazon Fan sediments focused on the general characteristics of bitumen composition. Of particular interest was the identification of distinct sedimentary facies on a molecular level. We investigated sediments from different fan environments (pelagic and hemipelagic sediments as well as active channel-levee sediments). On a qualitative molecular level (i.e., types of compounds detected), bitumen compositions of different fan environments are very similar to each other.

Relative differences in bitumen distribution in terms of marine vs. terrigenous origin appear to be significantly correlated with the dilution of the autochthonous signal by terrigenous detritus. These differences distinguish normal hemipelagic sediment (Site 942) from active channel-levee sediment (Site 940) of the Amazon Channel, where marine compounds represent a background signal. The range of the ratio of two distinct groups of lipids (i.e., terrigenous wax alcohols over plankton-derived fatty acids) corresponds very well to rough sedimentological estimates of sediment accumulation rates, which vary, depending on location and sea level, by more than 2 orders of magnitude. We suggest that this approach can be utilized for a rough estimate of the dilution of the autochthonous signal by terrigenous detritus in environments such as the Amazon Fan.
\end{abstract}

\section{INTRODUCTION}

The assemblage of organic matter components in marine sediments is controlled by a number of factors, including the supply of allochthonous organic matter from the continent (terrestrial plant material or eroded rock), the primary autochthonous productivity, preservation during and after deposition, redeposition of material on subaquatic slopes, diagenetic alteration within the sediment, and migration of mobile components from deeper sediment layers. Most of the predepositional factors will be influenced by climatic and related oceanographic changes (sea level and currents) that may eventually be reflected in the fossil organic matter composition. Drilling of late Quaternary sediments in the Amazon Fan by the Ocean Drilling Program (ODP) provided the opportunity to address this subject.

The Amazon Fan is located in the northwestern equatorial Atlantic on the Brazilian continental margin. Drilling during Leg 155 recovered more than $4000 \mathrm{~m}$ of late Quaternary sediments of mainly terrigenous origin. The predominant sediment components are silts and clays. Rapid burial has resulted in a strong remineralization of organic matter under anoxic conditions, leading to high concentrations of biogenic methane (Flood, Piper, Klaus, et al., 1995) in most of the recovered sediments. Sedimentation during the late Quaternary was mainly controlled by eustatic sea-level variations, with the Amazon River turbidity currents reaching the fan during times of lower sea level. During periods of high sea level, deposition of Amazon sediments took place on the shallow shelf, whereas sedimentation of pelagic calcareous clays at low rates occurred on the Amazon Fan.

Deep-sea fan environments of the world's major rivers play an important role as a sink of organic carbon in the global carbon cycle. The Amazon Fan is one of the most important organic carbon reservoirs on the world ocean's continental margins. Most of the sediments drilled during Leg 155 contain close to $1 \%$ organic carbon (Flood, Piper, Klaus, et al., 1995). Considering a minimal volume of

${ }^{1}$ Flood, R.D., Piper, D.J.W., Klaus, A., and Peterson, L.C. (Eds.), 1997. Proc. ODP, Sci. Results, 155: College Station, TX (Ocean Drilling Program).

${ }^{2}$ Institut für Chemie und Biologie des Meeres (ICBM), Carl von Ossietzky Universität Oldenburg, Postfach 2503, D-26111 Oldenburg, Federal Republic of Germany. k.hinrichs@ogc.icbm.uni-oldenburg.de
$700,000 \mathrm{~km}^{3}$ (Bouma et al., 1985; Damuth and Kumar, 1975) and an average bulk dry density of $2 \mathrm{t} / \mathrm{m}^{3}$ of the sediment, the extrapolated organic carbon content of the Amazon Fan accounts for $\sim 10^{13}$ t. The determination of the nature and provenance of the organic matter associated with Amazon Fan sediments is therefore of major relevance.

Previous organic geochemical studies of Amazon River and Fan sediments focused on bulk organic matter characteristics of surface sediments (P. Müller et al., unpubl. data), as well as lignin and humin substances suspended in the Amazon River (Hedges et al., 1986; Ertel et al., 1986). Little is known about the lipid composition of more deeply buried sediments on the Amazon Fan.

The main objectives of this preliminary study are (1) the characterization of the nature, origin, and early diagenesis of fossil lipids, (2) the identification of the major sedimentary facies on a molecular level, and (3) the eventual relation of distinct organofacies types to sea-level and paleoclimatic changes.

For organic geochemical studies, sediments from the following four sites were selected (Fig. 1): Site 938, on the eastern upper fan at an abandoned channel levee; Site 940, on the central fan at the Amazon Channel levee; Site 942, on the far western fan; and Site 946, on the lower fan at the Amazon Channel levee.

This report contains detailed molecular results derived mainly from sediments of Sites 940 and 942. However, these data should be representative for corresponding sedimentary facies penetrated at other locations drilled during Leg 155 . The discussion of total organic carbon (TOC) concentrations encompasses the four sites mentioned above.

\section{ANALYTICAL METHODS}

Sampling of sediments used for this study was carried out aboard the JOIDES Resolution at room temperature. Samples selected for organic geochemical investigation were then frozen and stored until work-up. Samples analyzed for the rapid determination of the Terrigenous Dilution Ratio (TDR') were originally taken for shipboard elemental analysis and, thus, were kept at ambient temperature for a long period. Prior to extraction, the deep-frozen and ground samples were stored at room temperature conditions. 


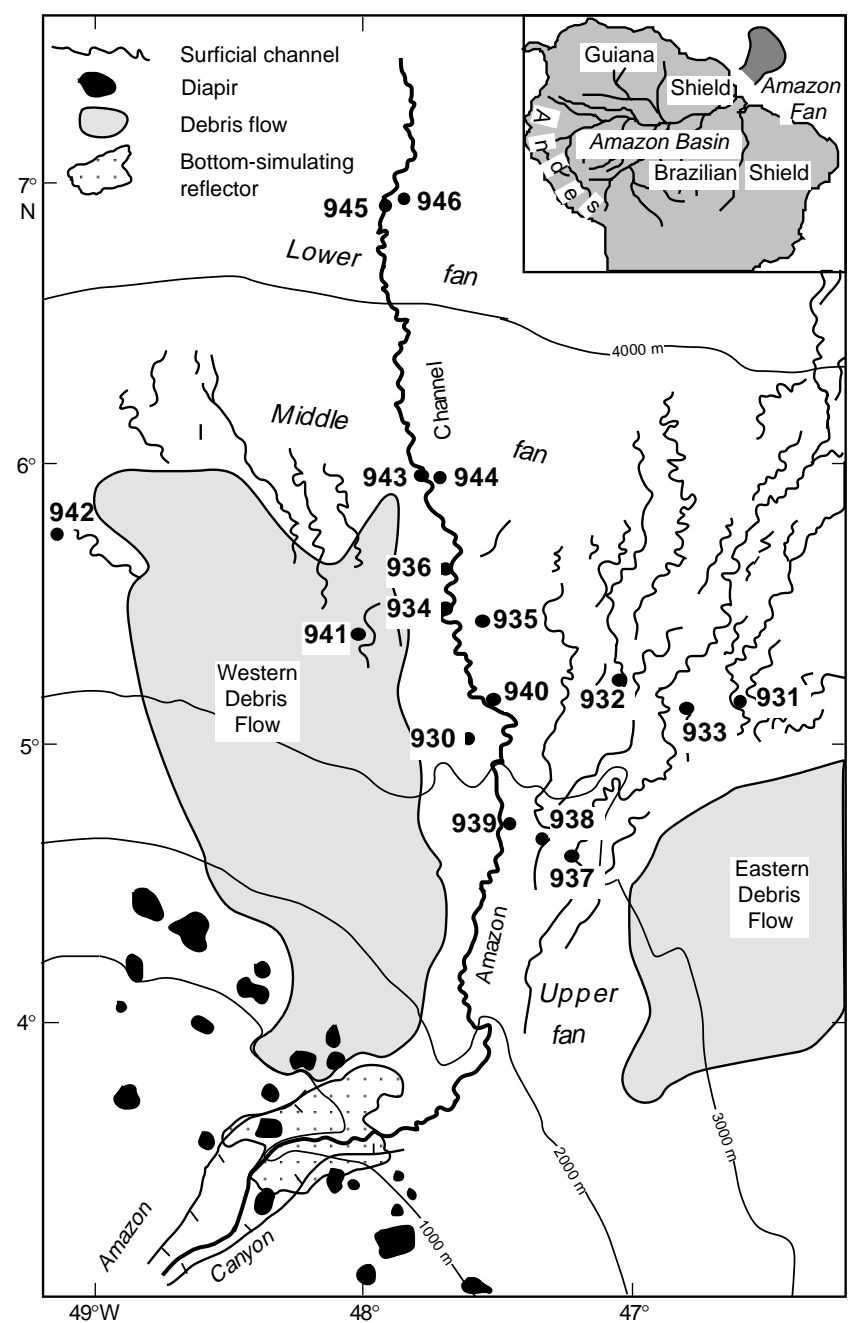

Figure 1. Map of the Amazon Fan showing locations of sites in relation to surficial channel systems. Sites selected for organic geochemical studies are Sites 938, 940, 942, and 946 (from Flood et al., 1995; modified from Damuth et al., 1988, and Manley and Flood, 1988).

All samples selected for detailed molecular analyses were freezedried and ground. After acidification of the sediment samples with hydrochloric acid for dissolution of carbonates, TOC contents were determined by combustion in a Ströhlein Coulomat 702 instrument at least in duplicate. Prior to analysis, excess $\mathrm{HCl}$ solution was evaporated by heating the samples to a temperature of about $150^{\circ} \mathrm{C}$.

About 30-50 g of dry sediment per sample was extracted in an ultrasonic bath with $2 \times 120 \mathrm{~mL}$ and $2 \times 80 \mathrm{~mL}$ of dichloromethane (containing 1\% methanol). Elemental sulfur, which was abundant in all terrigenous silty clays, was removed by adding acid-activated copper filings to the extract. For quantitation, internal standards (squalane, erucic acid $\left[n-\mathrm{C}_{22: 1}\right], 5 \alpha$-androstan-17-one, and $5 \alpha$-androstan-3 $\beta$-ol-17-one) were added to the total extracts. Average yields of desulfurized extracts from rapidly deposited terrigenous sediments ranged $\sim 10-12 \mathrm{mg} / \mathrm{g}$ TOC. The extract yields of organicmatter-lean interglacial calcareous clays exceeded these values by about a factor of 2 .

The total extracts were separated by medium-pressure liquid chromatography (MPLC; Radke et al., 1980) into fractions of aliphatic hydrocarbons, aromatic hydrocarbons, and polar compounds (NSO fraction). Carboxylic acids were separated from the NSO fraction by liquid chromatography on a column filled with $\mathrm{KOH}$-impregnated silica gel (63-200 $\mu \mathrm{m}$; a solution of $0.5 \mathrm{~g} \mathrm{KOH}$ in $10 \mathrm{~mL}$ iso-propanol was added to $4 \mathrm{~g}$ of silica gel). The nonacidic compounds were eluted from the column with $120 \mathrm{~mL}$ of dichloromethane. Following this, $50 \mathrm{~mL}$ of a solution of formic acid ( $2 \%$ in dichloromethane) transformed the potassium salts back to the free acids that were subsequently eluted with $80 \mathrm{~mL}$ of dichloromethane. The acid-free NSO fraction was subsequently separated into two fractions by flash chromatography (Still et al., 1978) under a moderate overpressure of nitrogen. The first subfraction contains mainly $n$-alcohols and ketones and the second sterols, triterpenoid alcohols, and multifunctional compounds. For this subfractionation, a $10 \mathrm{~mm} \times 200 \mathrm{~mm}$ column was filled with $5 \mathrm{~g}$ silica gel $60(40-63 \mu \mathrm{m}$, deactivated with $5 \%$ by weight of water) and washed with $50 \mathrm{~mL}$ of dichloromethane. Another $60 \mathrm{~mL}$ of dichloromethane were used to elute the fraction of $n$-alcohols and ketones at a rate of two drops per second. The sterols and more polar components were recovered from the column with $50 \mathrm{~mL}$ of a mixture of dichloromethane and methanol (10\% by volume). For molecular studies, the acid fraction was methylated with diazomethane, and the nonacidic polar subfractions were silylated with N-methyl-N-trimethylsilyl-trifluoroacetamide (MSTFA).

For the rapid determination of concentrations of selected lipids, 1to 4-g aliquots of ground sediment were extracted and desulfurized with the procedure described above. For extraction, we used a solvent/sediment ratio (volume/dry weight) of 20 for optimal reproducibility and consistency of results. For quantitation, $5 \mu \mathrm{g}$ of each $5 \alpha-$ androstan-17-one and $5 \alpha$-androstan-3 $\beta$-ol-17-one were added to the extract prior to desulfurization. After silylation, the extract was directly analyzed by gas chromatography (GC) to quantitate fatty acids and $n$-alcohols as trimethylsilyl (TMS) esters and ethers, respectively. The relative precision of the analytical procedure, based on duplicates, was in the range of $\pm 10 \%-15 \%$. As discussed in the "Molecular Stratigraphy" section, we defined a TDR as the ratio of the sum of terrigenous wax alcohols (TWA, $\mathrm{C}_{20}-\mathrm{C}_{32}$ ) over the sum of four marine fatty acids (MFA, $\mathrm{C}_{16: 1}, \mathrm{C}_{16: 0}, \mathrm{C}_{18: 1}, \mathrm{C}_{18: 0}$ )

$$
\mathrm{TDR}^{\prime}=\frac{\text { Terrigenous wax alcohols }\left[\Sigma\left(\mathrm{C}_{20}-\mathrm{C}_{32}\right)\right]}{\text { Marine fatty acids }\left[\Sigma\left(\mathrm{C}_{16: 1}, \mathrm{C}_{16: 0}, \mathrm{C}_{18: 1}, \mathrm{C}_{18: 0}\right)\right]}
$$

Normalization of this parameter by dividing the TDR' of each sample by the mean TDR value of analyzed Holocene sediments (= 890.25; data in Table 4) leads to a standardized TDR'. This way of normalization is reasonable due to the overall uniformity of the Holocene calcareous clays in the Amazon Fan.

$$
\begin{aligned}
& \mathrm{TDR}^{\prime}=\frac{\text { Terrigenous wax alcohols }\left[\Sigma\left(\mathrm{C}_{20}-\mathrm{C}_{32}\right)\right]}{\text { Marine fatty acids }\left[\Sigma\left(\mathrm{C}_{16: 1}, \mathrm{C}_{16: 0}, \mathrm{C}_{18: 1}, \mathrm{C}_{18: 0}\right)\right]} \\
& \cdot \frac{1}{\text { Mean TDR(Holocene clays })}
\end{aligned}
$$

GC was carried out on a Hewlett Packard 5890 series II instrument equipped with a Gerstel temperature-programmed cold injection system and a fused silica capillary column (J\&W DB 5, length $=$ $30 \mathrm{~m}$, inner diameter $=0.25 \mathrm{~mm}$, and film thickness $=0.25 \mu \mathrm{m}$ ). Helium was used as the carrier gas, and the temperature of the GC oven was programmed from $60^{\circ} \mathrm{C}$ (2 min isothermal) to $300^{\circ} \mathrm{C}(50 \mathrm{~min}$ isothermal) at a rate of $3^{\circ} \mathrm{C} / \mathrm{min}$. Gas chromatography/mass spectrometry (GC/MS) studies were performed under the GC conditions given above with the gas chromatograph coupled to a Finnigan SSQ $710 \mathrm{~B}$ mass spectrometer operated at $70 \mathrm{eV}$.

Stable carbon isotope ratios of individual compounds were determined on a Finnigan MAT 252 mass spectrometer coupled to the same type of gas chromatograph as described above. The $\delta^{13} \mathrm{C}$ values (relative to PDB) determined for $n$-carboxylic acids (as methyl esters) and $n$-alcohols (as TMS ethers) were corrected for the influence 
of the additional carbon atoms introduced by derivatization (e.g., Goñi and Eglinton, 1994).

Compound identifications are based on comparison of relative gas chromatographic retention times and mass spectra with those reported in the literature. Quantitations were performed relative to the amount of internal standards. Concentrations of alcohols (detected as TMS ethers) were calculated from their ratios relative to the injection standard behenic acid methyl ester (BAME) or, in case of neutral fractions and total extracts, relative to the internal standard $5 \alpha$-androstan-3ß-ol-17-one (as TMS derivative).

\section{RESULTS AND DISCUSSION}

\section{Concentrations of Organic Carbon at Selected Sites}

All sediments selected for detailed molecular studies were investigated for their TOC content. The results were combined with data obtained from shipboard analyses and are illustrated in Figure 2 and listed in Table 1 for Sites 938, 940, 942, and 946. The results of shipboard and shore-based analyses of closely spaced samples are consistent in most of the cases. Where differences do occur, they are within the range of those from analyses of closely spaced samples aboard the JOIDES Resolution. The TOC contents in calcareous Holocene clays from Site 938 range from $0.29 \%$ to $0.52 \%$ (Fig. 2A). The more deeply buried late Pleistocene terrigenous silty clays are typically characterized by TOC contents between $0.8 \%$ and $1 \%$. Lower values correspond to sediments with larger grain sizes, and TOC contents of about $0.3 \%$ occur in samples described as silt or sand.

The organic carbon distribution at Site 940 (Fig. 2B) on the flank of the Amazon Channel levee is similar to that at Site 938. TOC contents in surface and subsurface Holocene sediments are moderately lower, and typical values of $0.8 \%-1 \%$ occur in most of the upper Pleistocene muds. Sediment sections enriched in coarser grains contain TOC down to less than $0.1 \%$.

Sediments at Site 942, selected as a hemipelagic reference site, are characterized by a TOC profile different from those at Sites 938 and 940. The sediments recovered at Site 942 span a full interglacial cycle and extend to oxygen isotopic Stage 6 (Showers et al.; Schneider et al., both this volume). As at other sites, the Holocene sediments that cover the entire fan with a layer of uniform thickness of $\sim 0.5-1 \mathrm{~m}$, contain $0.3 \%-0.5 \%$ TOC (Fig. 2C). In contrast to other sites, most of the underlying sediment down to a depth of 70 meters below seafloor (mbsf) at Site 942 consists of fine-grained hemipelagic deposits. This sequence has been dated to range from oxygen isotopic Stage 5e to Stage 2. It carries relatively low amounts of organic carbon, ranging from $0.8 \%$ in the top $20 \mathrm{mbsf}$ to $\sim 0.3 \%$ in hemipelagic muds and even lower values in sandy turbidites. Like the Holocene sediments, calcareous clays deposited during the last sea-level maximum during Stage 5 e contain $0.3 \%-0.5 \%$ TOC. The relatively low TOC concentrations observed in the hemipelagic sequence is possibly related to a slower sediment accumulation, which is lower by about a factor of 10-100 than those of the channel levee muds (estimated $>10 \mathrm{~m} / \mathrm{k} . \mathrm{y}$.), where preservation of organic matter most likely was supported by rapid burial. The sedimentary sequence from $70 \mathrm{mbsf}$ down to the bottom of Hole 942A (total depth $=177.6 \mathrm{mbsf}$ ) deposited during Stage 6 , is considered to represent the crest of an abandoned levee where the rapid deposition of terrigenous muds took place. The downhole transition to terrigenous levee muds coincides with a sharp increase of TOC concentrations to values of $1 \%$ that stay at this level down to the bottom of Hole 942A.

The lower fan at Site 946 consists of sediments having a wide range of grain sizes. Due to a high abundance of coarser grained sediments, the core recovery was only $62 \%$. Sediments analyzed for bulk organic geochemical parameters were mainly taken in intervals of clays and silts. The TOC record presented in Figure 2D therefore is not continuous and is only representative for finer grained sediments. Samples analyzed in the top $110 \mathrm{mbsf}$ represent terrigenous silts and clays with TOC contents in most of the samples between $0.5 \%$ and $1.3 \%$. A noticeable feature of sediments recovered at Site 946 is the presence of coarse terrestrial plant debris. In two samples with abundant plant debris (Samples 155-946A-5H-5, 63-64 cm, 42.13 mbsf; $8 \mathrm{H}-2,124-130 \mathrm{~cm}, 66.63 \mathrm{mbsf}$ ), TOC concentrations reach $4.11 \%$ and $3.39 \%$, respectively. The underlying sediment interval, which corresponds to last interglacial bioturbated calcareous mud (lithologic Unit IV; Flood, Piper, Klaus, et al., 1995), is characterized by notably lower TOC contents, ranging from $0.28 \%$ to $0.66 \%$. Samples in the depth interval from 159.22 to 270.01 mbsf display TOC contents from $0.43 \%$ to $0.88 \%$. Two samples $(155-946 \mathrm{~A}-23 \mathrm{X}-3,107-110 \mathrm{~cm}$, 211.57 mbsf; 24X-1, 97-100 cm, 218.07 mbsf) from lithologic Unit VI, an interval of older interglacial bioturbated calcareous mud, contain $0.46 \%$ and $0.48 \%$ TOC, respectively.

In summary, organic carbon concentrations distinguish four sediment types (for comparison, see "Organic Geochemistry" sections in Flood, Piper, Klaus, et al., 1995). Surficial Holocene calcareous clays as well as older interglacial calcareous clays are commonly characterized by TOC contents between $0.3 \%$ and $0.5 \%$; rapidly buried terrigenous silty clays mostly contain between $0.8 \%$ and $1 \%$ TOC. Sediments with grain sizes in the sand range, often occurring as discrete layers, commonly contain very low TOC concentrations down to less than $0.1 \%$. Uncommonly high TOC concentrations were observed, especially in sediments of the lower fan (Site 946) with abundant plant debris (Fig. 2D).

\section{Molecular Investigations}

\section{General Lipid Characteristics}

In general, lipid compositions of Amazon Fan sediments are complex with terrigenous lipids being the dominant components. Striking differences in molecular composition distinguish interglacial calcareous clays from glacial silty clays. Non-aromatic hydrocarbon fractions are dominated by terrigenous wax alkanes. Concentrations of terrigenous wax alkanes are generally lower than those of terrigenous wax alcohols (concentrations are reported in the "Molecular Stratigraphy" section, this paper). Relatively uniform compound group ratios were observed in all samples analyzed. Polycyclic steroid and triterpenoid biomarkers are present only in minor concentrations with diploptene of bacterial origin as the major compound. However, a decision as to whether diploptene results from autochthonus or allochthonous bacterial activities (it may also be derived from soils in the hinterland; Prahl et al., 1992) cannot be made without any further analyses. Due to the simplicity of these fractions, no further detailed studies were performed. A detailed study on the molecular composition of aromatic hydrocarbons extracted from a subset of Site 940 samples discussed here is presented by Budzinski et al. (this volume).

Figure 3 shows a representative reconstructed ion chromatogram (RIC) from GC/MS analysis of the neutral fraction of a typical sample from Site 940 (Sample 155-940A-23X-4, 83-90 cm, 205.40 mbsf), composed of Amazon Channel levee silty clay. The diagram illustrates the predominance of terrigenous components and the complexity of the lipid composition, especially in the elution range of steroid and triterpenoid alcohols. Compounds identified are marked with symbols and listed in Table 2 . The predominant compound class in typical terrigenous sediments of glacial age are long-chain $n$-alcohols with carbon number distributions (Eglinton and Hamilton, 1967) and carbon isotopic signatures $\left(\delta^{13} \mathrm{C}=-35 \%\right.$ o to $-33 \%$ o for the major $\mathrm{C}_{22}, \mathrm{C}_{24}, \mathrm{C}_{26}$, and $\mathrm{C}_{28} n$-alcohols) characteristic of lipids derived from cuticles of higher land plants (Rieley et al., 1991). Total wax alcohol $\left(\sum \mathrm{C}_{20}-\mathrm{C}_{32}\right)$ concentrations in silty clays from Sites 940 and 942 exceed $2000 \mu \mathrm{g} / \mathrm{g}$ TOC. A detailed discussion of wax alcohol concentrations will follow in the "Molecular Stratigraphy" section. $n$-Alkanols with chain lengths below 20, which are indicative of marine algae (Weete, 1976) or bacteria (Albro, 1976), were not observed in any of the Amazon Fan sediments analyzed. Further major compounds characteristic of higher land plant contributions are the coe- 

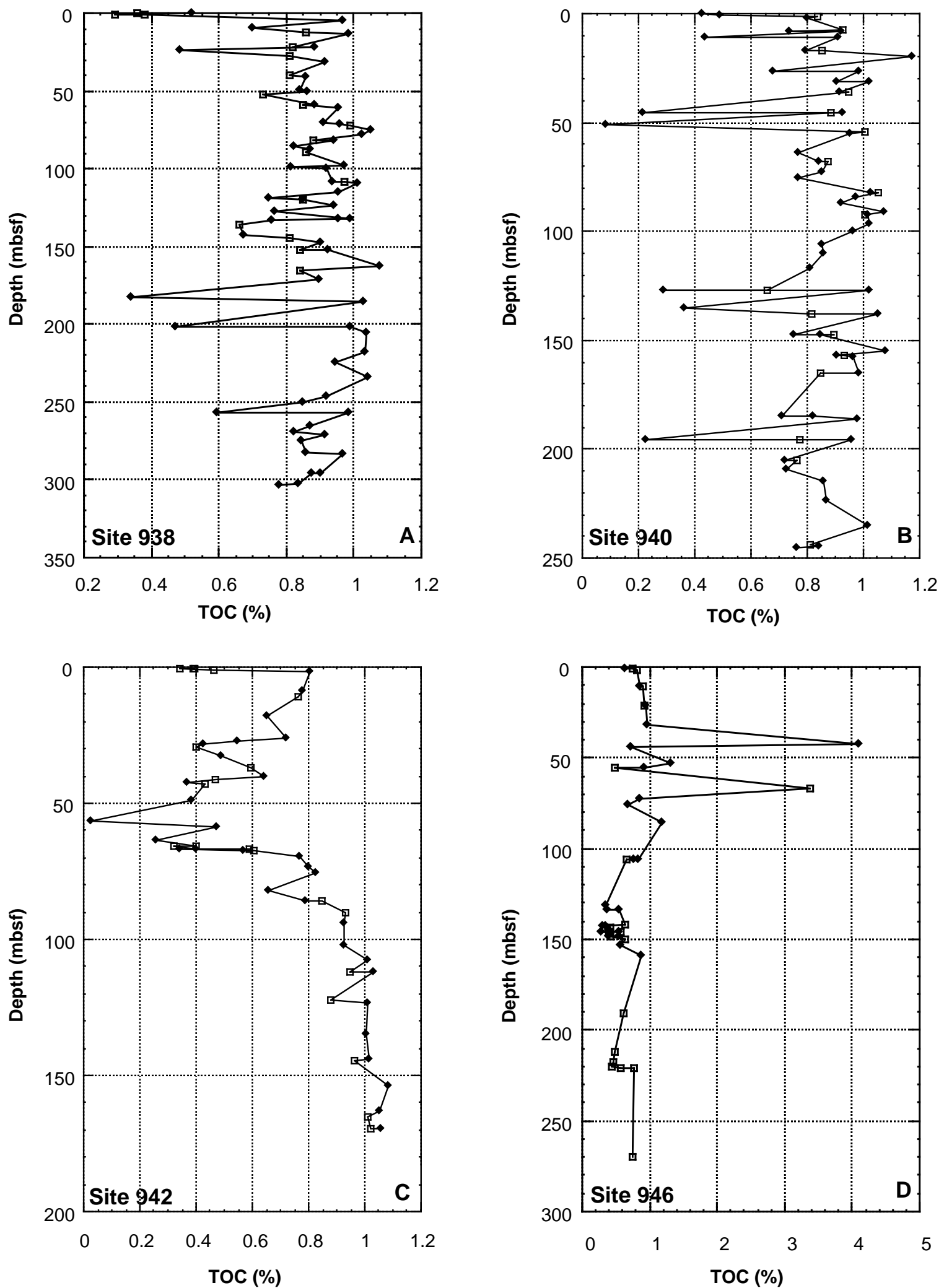

- TOC (\%)-shipboard data

- TOC (\%)-shore-based data

Figure 2. Concentration profiles of total organic carbon (TOC) from Sites (A) 938, (B) 940, (C) 942, and (D) 946. Data are listed in Table 1. 
Table 1. Total organic carbon concentrations for core samples from selected sites.

\begin{tabular}{|c|c|c|}
\hline $\begin{array}{l}\text { Core, section, } \\
\text { interval }(\mathrm{cm})\end{array}$ & $\begin{array}{l}\text { Depth } \\
\text { (mbsf) }\end{array}$ & $\begin{array}{l}\text { TOC } \\
(\%)\end{array}$ \\
\hline $\begin{array}{l}155-938 \mathrm{~A}- \\
1 \mathrm{H}-1,10-16 \\
1 \mathrm{H}-1,50-56 \\
1 \mathrm{H}-1,76-83 \\
2 \mathrm{H}-4,54-60 \\
3 \mathrm{H}-4,31-37 \\
4 \mathrm{H}-2,92-98 \\
5 \mathrm{H}-3,96-102 \\
6 \mathrm{H}-6,43-49 \\
7 \mathrm{H}-4,90-96 \\
8 \mathrm{H}-6,41-47 \\
9 \mathrm{H}-7,33-40 \\
10 \mathrm{X}-5,27-33 \\
12 \mathrm{X}-4,87-93 \\
13 \mathrm{X}-5,108-114 \\
15 \mathrm{X}-4,33-39 \\
16 \mathrm{X}-5,56-62 \\
17 \mathrm{X}-1,128-134 \\
18 \mathrm{X}-4,107-113\end{array}$ & $\begin{array}{c}0.13 \\
0.53 \\
0.8 \\
12.29 \\
21.84 \\
27.87 \\
39.58 \\
51.61 \\
59.31 \\
72.18 \\
81.99 \\
89.07 \\
108.1 \\
119.51 \\
136.32 \\
147.79 \\
152.11 \\
165.48\end{array}$ & $\begin{array}{l}0.36 \\
0.29 \\
0.38 \\
0.86 \\
0.82 \\
0.81 \\
0.81 \\
0.73 \\
0.85 \\
0.99 \\
0.88 \\
0.86 \\
0.97 \\
0.85 \\
0.66 \\
0.81 \\
0.84 \\
0.84\end{array}$ \\
\hline $\begin{array}{l}155-940 \mathrm{~A}- \\
1 \mathrm{H}-2,20-25 \\
2 \mathrm{H}-4,41-47 \\
3 \mathrm{H}-4,45-50 \\
5 \mathrm{H}-5,50-56 \\
6 \mathrm{H}-4,102-108 \\
7 \mathrm{H}-4,54-61 \\
8 \mathrm{H}-6,50-57 \\
10 \mathrm{X}-4,48-55 \\
11 \mathrm{X}-6,34-42 \\
15 \mathrm{X}-3,40-45 \\
16 \mathrm{X}-4,53-59 \\
17 \mathrm{X}-4,36-44 \\
18 \mathrm{X}-4,37-43 \\
19 \mathrm{X}-3,33-39 \\
22 \mathrm{X}-4,25-31 \\
23 \mathrm{X}-4,83-90 \\
27 \mathrm{X}-4,67-73\end{array}$ & $\begin{array}{r}1.69 \\
7.55 \\
17.27 \\
36.34 \\
45.84 \\
54.33 \\
67.71 \\
81.94 \\
92.53 \\
126.71 \\
137.70 \\
147.50 \\
157.02 \\
165.26 \\
195.53 \\
205.40 \\
244.20\end{array}$ & $\begin{array}{l}0.83 \\
0.93 \\
0.85 \\
0.95 \\
0.89 \\
1.01 \\
0.88 \\
1.05 \\
1.01 \\
0.66 \\
0.82 \\
0.89 \\
0.93 \\
0.85 \\
0.78 \\
0.76 \\
0.81\end{array}$ \\
\hline $\begin{array}{l}155-942 \mathrm{~A}- \\
2 \mathrm{H}-5,80-86 \\
4 \mathrm{H}-4,110-117 \\
5 \mathrm{H}-4,64-70 \\
5 \mathrm{H}-7,130-137 \\
6 \mathrm{H}-1,136-143 \\
8 \mathrm{H}-4,25-29 \\
8 \mathrm{H}-4,47-51 \\
8 \mathrm{H}-5,16-22 \\
8 \mathrm{H}-5,72-78 \\
10 \mathrm{H}-5,68-74 \\
11 \mathrm{H}-2,5-11 \\
14 \mathrm{X}-2,33-39 \\
15 \mathrm{X}-2,106-112 \\
17 \mathrm{X}-4,96-103 \\
19 \mathrm{X}-5,90-96 \\
20 \mathrm{X}-2,25-31\end{array}$ & $\begin{array}{r}10.63 \\
28.12 \\
37.14 \\
41.31 \\
43.20 \\
65.57 \\
65.79 \\
66.99 \\
67.55 \\
86.00 \\
90.07 \\
111.96 \\
122.29 \\
144.50 \\
165.23 \\
169.68\end{array}$ & $\begin{array}{l}0.77 \\
0.40 \\
0.59 \\
0.47 \\
0.43 \\
0.40 \\
0.32 \\
0.59 \\
0.61 \\
0.85 \\
0.93 \\
0.95 \\
0.88 \\
0.96 \\
1.01 \\
1.02\end{array}$ \\
\hline $\begin{array}{l}155-942 \mathrm{C}- \\
1 \mathrm{H}-1,33-39 \\
1 \mathrm{H}-1,41-47 \\
1 \mathrm{H}-1,60-66 \\
1 \mathrm{H}-1,93-98\end{array}$ & $\begin{array}{l}0.36 \\
0.44 \\
0.63 \\
0.95\end{array}$ & $\begin{array}{l}0.40 \\
0.39 \\
0.34 \\
0.46\end{array}$ \\
\hline $\begin{array}{l}155-946 \mathrm{~A}- \\
1 \mathrm{H}-1,85-91 \\
1 \mathrm{H}-2,50-56 \\
2 \mathrm{H}-3,61-67 \\
3 \mathrm{H}-4,32-38 \\
7 \mathrm{H}-1,118-124 \\
8 \mathrm{H}-2,124-130 \\
12 \mathrm{H}-3,130-136 \\
16 \mathrm{X}-2,27-30 \\
16 \mathrm{X}-3,70-73 \\
16 \mathrm{X}-4,117-120 \\
16 \mathrm{X}-5,19-22 \\
16 \mathrm{X}-6,120-123 \\
17 \mathrm{X}-1,20-23 \\
21 \mathrm{X}-2,89-95 \\
23 \mathrm{X}-3,107-110 \\
24 \mathrm{X}-1,97-100 \\
24 \mathrm{X}-3,18-21 \\
24 \mathrm{X}-3,76-79 \\
24 \mathrm{X}-3,94-97 \\
29 \mathrm{X}-4,11-18\end{array}$ & $\begin{array}{r}0.88 \\
2.03 \\
10.69 \\
21.32 \\
55.71 \\
66.63 \\
106.33 \\
141.79 \\
143.72 \\
145.68 \\
146.2 \\
148.71 \\
149.81 \\
190.62 \\
211.63 \\
218.08 \\
220.29 \\
220.87 \\
221.05 \\
270.05\end{array}$ & $\begin{array}{l}0.74 \\
0.81 \\
0.90 \\
0.93 \\
0.49 \\
3.39 \\
0.66 \\
0.63 \\
0.41 \\
0.40 \\
0.56 \\
0.41 \\
0.64 \\
0.61 \\
0.48 \\
0.46 \\
0.43 \\
0.58 \\
0.76 \\
0.75\end{array}$ \\
\hline
\end{tabular}

Note: $\mathrm{TOC}=$ total organic carbon. luting components 24 -ethyl-5 $\alpha(\mathrm{H})$-cholestan- $3 \beta$-ol $(\mathrm{k})$ and $\alpha$-amyrin (1), as well as the triterpenoid ketone friedelan-3-one ("friedelin,"p). Concentrations of the latter compound measured in 11 samples range from $310 \mathrm{ng} / \mathrm{g}$ dry sediment ( $36 \mu \mathrm{g} / \mathrm{g}$ TOC) to $970 \mathrm{ng} / \mathrm{g}$ dry sediment $(117 \mu \mathrm{g} / \mathrm{g}$ TOC).

Another compound present in relatively high concentrations is the bacterial marker $17 \beta(\mathrm{H}), 21 \beta(\mathrm{H})$-dihomo-hopan-32-ol (r). The assignment of the sterical configuration at C-17 and C-21 is tentative and based on comparison with literature data (Venkatesan et al., 1990) and on the retention time relative to other alcohols of the homohopane series that are present in all samples from Site 940. Alcohols of the homo-hopane series are known as degradation products of bacteriohopanepolyols and have previously been found in soils and peats (Gramberg et al., 1995) and marine sediments (Rohmer et al., 1980; Dastillung et al., 1980; Venkatesan et al., 1990). As in the case of diploptene, a decision as to whether the presence of these hopanoids is related to allochthonous and/or to autochthonous bacterial activity cannot be made on the basis of the data available so far. The concentration of the main hopanoid compound (r) in the investigated samples varies by 1 order of magnitude from 84 to $1015 \mathrm{ng} / \mathrm{g}$ dry sediment (10-101 $\mu \mathrm{g} / \mathrm{g}$ TOC). Other hopanoid alcohols occur only in minor amounts (compounds q, s, t, and u; Table 2) in the investigated Amazon Fan sediments. Assignment of the sterical configuration (C$17, \mathrm{C}-21$ ) and the position of the methyl group at C-2 or C-3 in the Aring methylated hopanoid alcohols could not be made due to a lack of standards. The hopanoid ketone 22,29,30-trinor-17( $\alpha) \mathrm{H}$-hopan-21one (d), which elutes just before $n$-octacosanol, is probably of bacterial origin. This compound has been found in a variety of studies in different environments like the California Margin area (McEvoy, 1983), in Japan Trench sediments (Brassell, 1980), and in lacustrine Ménat shales of Eocene age (Dastillung, 1976).

\section{Steroids}

The distributions of free sterols of four representative sediments from Site 942, deposited under different paleoenvironmental conditions, illustrate how sedimentation patterns are reflected in the molecular composition (Fig. 4). A summary of compounds identified in the sterol fractions is given in Table 3. The samples selected include two sediments deposited during periods of sea-level highstand, a typical Holocene sample $(155-942 \mathrm{C}-1 \mathrm{H}-1,41-47 \mathrm{~cm})$, and a sample from the Eemian Interglacial (155-942A-8H-4, 47-51 cm; Stage 5e; chronology by Showers et al. and Schneider et al., both this volume). The other two samples consist of terrigenous mud and were deposited during times of lower sea level. One sample (155-942A-6H-1, 136$143 \mathrm{~cm}$; Stage 3), a heavily bioturbated mud, represents a period when hemipelagic sedimentation occurred on the northwestern margin of the Amazon Fan at moderate accumulation rates $(0.5$ to $1 \mathrm{~m} /$ k.y.; Flood, Piper, Klaus, et al., 1995). The fourth sample (155-942A$11 \mathrm{H}-2,5-11 \mathrm{~cm}$; Stage 6 ) is typical for rapidly deposited terrigenous silty clay in a levee system.

In general, the sterol distributions of Amazon Fan sediments are quite simple with 4-desmethyl sterols being the major compound class. The relatively simple sterol pattern is common for an environment with low to moderate primary productivity. In contrast, sterol compositions from high-productivity areas with a variety of source organisms may contain up to 70 different compounds (Brassell and Eglinton, 1981; Hinrichs et al., 1995a, 1995b).

The dominant sterol in the Holocene (Fig. 4A, Sample 155-942C$1 \mathrm{H}-1,41-47 \mathrm{~cm}$ ) as well as the Eemian sediment (Fig. 4C, Sample $155-942 \mathrm{~A}-8 \mathrm{H}-4,47-51 \mathrm{~cm})$ is the ubiquitous cholest-5-en-3 $\beta$-ol (e). Dinosterol or 24 -ethyl- $5 \alpha(\mathrm{H})$-cholestan- $3 \beta$-ol $(\mathrm{g})$ are the secondmost abundant compounds. Due to the common predominance of cholest-5-en-3 $\beta$-ol in pelagic sediments, we interpret this compound as a marine signal that is probably contributed to the sediment by marine plankton (Volkman, 1986; Volkman et al., 1987). Dinoflagel- 


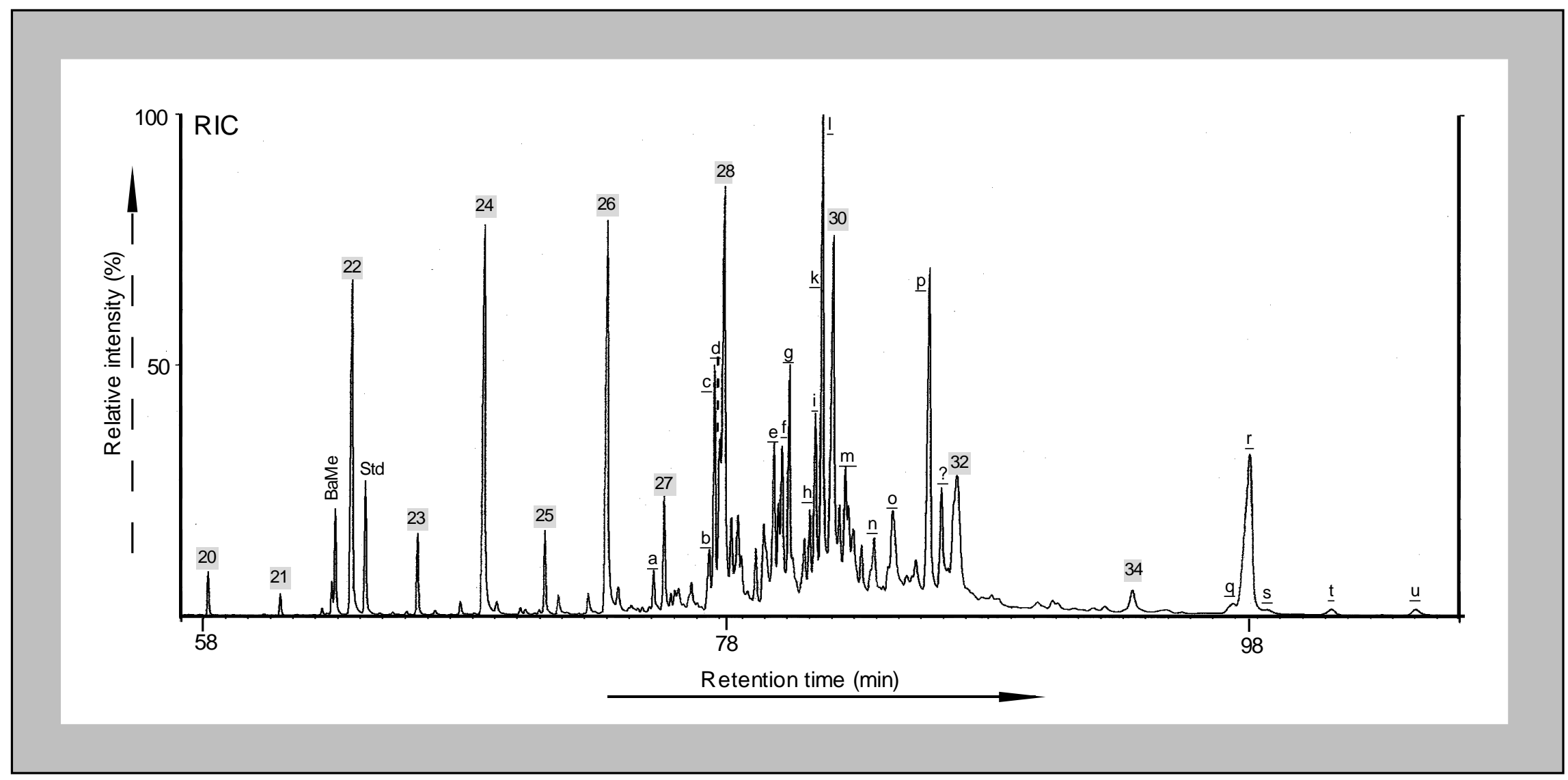

Figure 3. Partial reconstructed ion chromatogram of the neutral fraction of a representative sample (155-940A-23X-4, 83-90 cm) from Site 940 . The labeled identified compounds are listed in Table 2. $n$-alcohols (numbers), the internal standard ( $5 \alpha$-androstan-3 $\beta$-ol-17-one-Std), and the injection standard (BaMe) are marked in the chromatogram. 
Table 2. Major compounds identified in the neutral fraction of a representative sample from Site 940 together with source assignments.

\begin{tabular}{|c|c|c|}
\hline Symbol & Compound & Origin \\
\hline a & 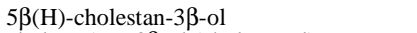 & Reduction of cholesterol \\
\hline b & cholest-5-en-3 $\beta$-ol (cholesterol) & Ubiquitous, marine \\
\hline c & 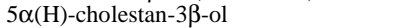 & Reduction of cholesterol \\
\hline d & $22,29,30$-trinor $-17 \alpha(\mathrm{H})$-hopan-21-one & Bacteria \\
\hline $\mathrm{e}$ & 24 -methyl- $5 \alpha(\mathrm{H})$-cholestan- $3 \beta$-ol & Marine algae \\
\hline $\mathrm{f}$ & 24-ethylcholesta-5, 22(E)-dien-3 $\beta$-ol & Plants \\
\hline $\mathrm{g}$ & 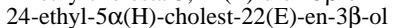 & Plants \\
\hline $\mathrm{h}$ & taraxerol & Plants \\
\hline $\mathrm{i}$ & 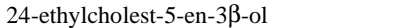 & Plants \\
\hline $\mathrm{k}$ & 24 -ethyl- $5 \alpha(\mathrm{H})$-cholestan-3 $\beta$-ol & Plants \\
\hline 1 & $\beta$-amyrin & Plants \\
\hline $\mathrm{m}$ & $\alpha$-amyrin & Plants \\
\hline $\mathrm{n}$ & unknown $\mathrm{C}_{29}$-stenone & \\
\hline o & triacontan-1-on-17-ol ? & Marine algae? \\
\hline $\begin{array}{l}\mathrm{p} \\
?\end{array}$ & $\begin{array}{l}\text { friedelan-3-one } \\
\text { unknown compound }\end{array}$ & Plants \\
\hline$\dot{q}$ & 2- or 3-methyl-dihomo-hopan-32-ol & Bacteria \\
\hline $\mathrm{r}$ & $17 \beta(\mathrm{H}), 21 \beta(\mathrm{H})$-dihomo-hopan-32-ol & Bacteria \\
\hline $\mathrm{s}$ & $17 \alpha(\mathrm{H}), 21 \beta(\mathrm{H})$-trihomo-hopan-33-ol & Bacteria \\
\hline $\mathrm{t}$ & 2- or 3-methyl-homo-hop-9(11)-en-31-ol & $\begin{array}{l}\text { Acetobacter spp. } \\
\text { M. Rohmer (pers. comm., } \\
\text { 1995) }\end{array}$ \\
\hline $\mathrm{u}$ & 2- or 3-methyl-dihomo-hopan-32-ol & Bacteria \\
\hline
\end{tabular}

Notes: Representative sample is 155-940A-23X-4, 83-90 cm. Symbols as in Figure 3.

lates are assumed to be the major source of dinosterol in marine sediments (Boon et al., 1979).

The sterol distribution of the hemipelagic bioturbated mud sample (Fig. 4B; Sample 155-942A-6H-1, 136-143 cm) is dominated by dinosterol. Dinoflagellates are considered to have significantly contributed to the autochthonous organic matter in this sample. Major compounds in the terrigenous silty clay sample (Fig. 4D; 155-942A-11H$2,5-11 \mathrm{~cm})$ are the triterpene alcohol $\alpha$-amyrin (B) and 24-ethyl$5 \alpha(\mathrm{H})$-cholestan-3 $\beta$-ol $(\mathrm{p})$, both typical biomarkers of higher land plants. Due to the coelution of these compounds on the gas chromatographic column used, determination of their absolute concentrations was impeded. The most striking feature in the total ion chromatogram of Sample 155-942A-11H-2, 5-11 cm (Fig. 4D), is the poor resolution that results from a complex mixture of a variety of terrigenous components with triterpenoid structures (mostly triterpenoid alcohols and ketones, tentatively identified by diagnostic ions in mass spectrometric analysis). For a detailed investigation of these compounds, which occur in a large number at relatively low concentrations, a more sophisticated method of liquid chromatographic separation (e.g., Gramberg et al., 1995) will have to be employed.

Figure 5 shows the sterol distribution of a sample from Site 940 (Sample 155-940A-5H-5, 50-56 cm) located on the flank of the Amazon Channel levee. The levees of active channels in the upper and central fan are characterized by extremely high sedimentation rates estimated to range from 10 to $25 \mathrm{~m} / \mathrm{k}$.y. (Flood, Piper, Klaus, et al., 1995). The major part of the sedimentary sequence at Site 940 is comprised of sediments from the last glacial period (Schneider et al., this volume). The sterol distribution in this sample is less complex than that of the also rapidly accumulated sediment from Site 942 (Sample 155-942A-11H-2, 5-11 cm; Fig. 4D), suggesting that sterols in the Site 940 sample were contributed by a smaller number of source organisms. The dominant compound is 24-ethyl-5 $\alpha(\mathrm{H})$ cholestan-3 $\beta$-ol (p), most likely derived from the geochemical reduction of the higher-land plant precursor 24-ethylcholest-5-en-3 $\beta$-ol. The concentration of this single compound is $116 \mu \mathrm{g} / \mathrm{g}$ TOC, and thus significantly exceeds those of other polycyclic biomarkers in samples from Site 942. Other major compounds (o, n, and m; Table 3) in Sample $155-940 \mathrm{~A}-5 \mathrm{H}-5,50-56 \mathrm{~cm}$, can also be related to higher land plant sources (Volkman, 1986). As in the Site 942 sediments, the double bond homologs cholest-5-en-3 $\beta$-ol (e) and $5 \alpha(\mathrm{H})$-cholestan-
$3 \beta$-ol (f) are hard to assign to a specific source. Compound-specific stable carbon isotopic data may provide additional information.

4-Methylsterols, like dinosterol (q) and its saturated analogs (s and $\mathrm{t}$ ), were not detected in Sample 155-940A-5H-5, 50-56 cm. We suggest that this observation demonstrates the dilution of the autochthonous marine signal by terrigenous material in these extremely rapidly deposited silty clays rather than spatial differences in primary productivity of dinoflagellates. An additional compound of marine origin, 24-methylcholesta-5,22-dien-3 $\beta$-ol (g, brassicasterol), is primarily contributed to marine sediments by diatoms (Volkman, 1986). This compound is generally present in low concentrations in the rapidly accumulated sediments at Sites 940 and 942, indicating a minor contribution of diatoms to the autochthonous organic matter in Amazon Fan sediments. However, the absence of this compound in the pelagic sediments from Stages 1 and 5e may be related to both low diatom productivity in the surface waters above the fan as well as a lower stability of brassicasterol relative to other sterols under the given depositional conditions during periods of sea-level highstand. In addition, the presence of brassicasterol in terrigenous muds may be related to the fact that Amazon River sediments were initially deposited on the continental shelf during periods of high sea level. At present, the bulk marine productivity occurs on the continental shelf (DeMaster and Pope, 1996). Therefore, marine signals in glacial terrigenous muds may, at least partly, be derived from shelf productivity during periods of high sea level and consecutive resedimentation into the Amazon Fan.

\section{Fatty acids}

Preliminary investigation of the carboxylic acid fractions of samples from Sites 940 and 942 focused on the distributions of $n$-fatty acids, which are the major compound class in this fraction. In all investigated sediments, the distribution is dominated by fatty acids in the carbon number range from 14 to 18 with hexadecanoic acid $\left(\mathrm{C}_{16: 0}\right)$ being the major compound, followed by hexadecenoic acid $\left(\mathrm{C}_{16: 1}\right)$, octadecanoic acid $\left(\mathrm{C}_{18: 0}\right)$, and octadecenoic acid $\left(\mathrm{C}_{18: 1}\right)$, the latter three having similar relative concentrations. Surprisingly, and in contrast to wax alkanes and wax alcohols, long-chain fatty acids in the carbon number range typical for the contribution of higher land plant waxes are present only at relatively low concentrations in all terrigenous silty clay samples analyzed from Sites 940 and 942 . The ratio of the sum of two major fatty acids $\mathrm{C}_{24: 0}$ and $\mathrm{C}_{26: 0}$, over the sum of the two major $n$-alcohols $\mathrm{C}_{26}$ and $\mathrm{C}_{28}$, plus the fatty acids $\mathrm{C}_{24: 0}$ and $\mathrm{C}_{26: 0}$, varies from 0.01 to 0.25 , with an average value of $0.09(n=43)$. At this stage of our study, we can only speculate about the fate of the terrigenous long-chain fatty acids. We suggest that free fatty acids of this type were preferentially lost during transport from land due to their higher polarity relative to the wax alcohols, but that a certain portion may still be bound to the macromolecular organic matter; this portion may only be retrieved by selective chemical degradation (hydrolysis) of the insoluble organic matter.

The major fatty acids in four selected samples from Site 940 were analyzed by gas chromatography-isotopic ratio monitoring-mass spectrometry (GC-IRM-MS) to obtain more specific information about their origin. Organic matter of higher land plants is commonly more depleted in the stable carbon isotope ${ }^{13} \mathrm{C}$ than organic matter produced by marine phytoplankton. Lipids of these different groups of organisms reflect this difference and can therefore be assigned to source organisms by determining their stable carbon isotopic composition. The saturated and unsaturated $\mathrm{C}_{16}$ and $\mathrm{C}_{18}$ fatty acids in Amazon Fan sediment extracts exhibit carbon isotopic ratios ranging from $-24.7 \%$ o to $-19.7 \%$ (PDB), and, thus, are typical for lipids derived from marine organisms (e.g., Freeman et al., 1995). We interpret the short-chain fatty acids as an autochthonous signal produced by marine plankton. This interpretation is supported by the 


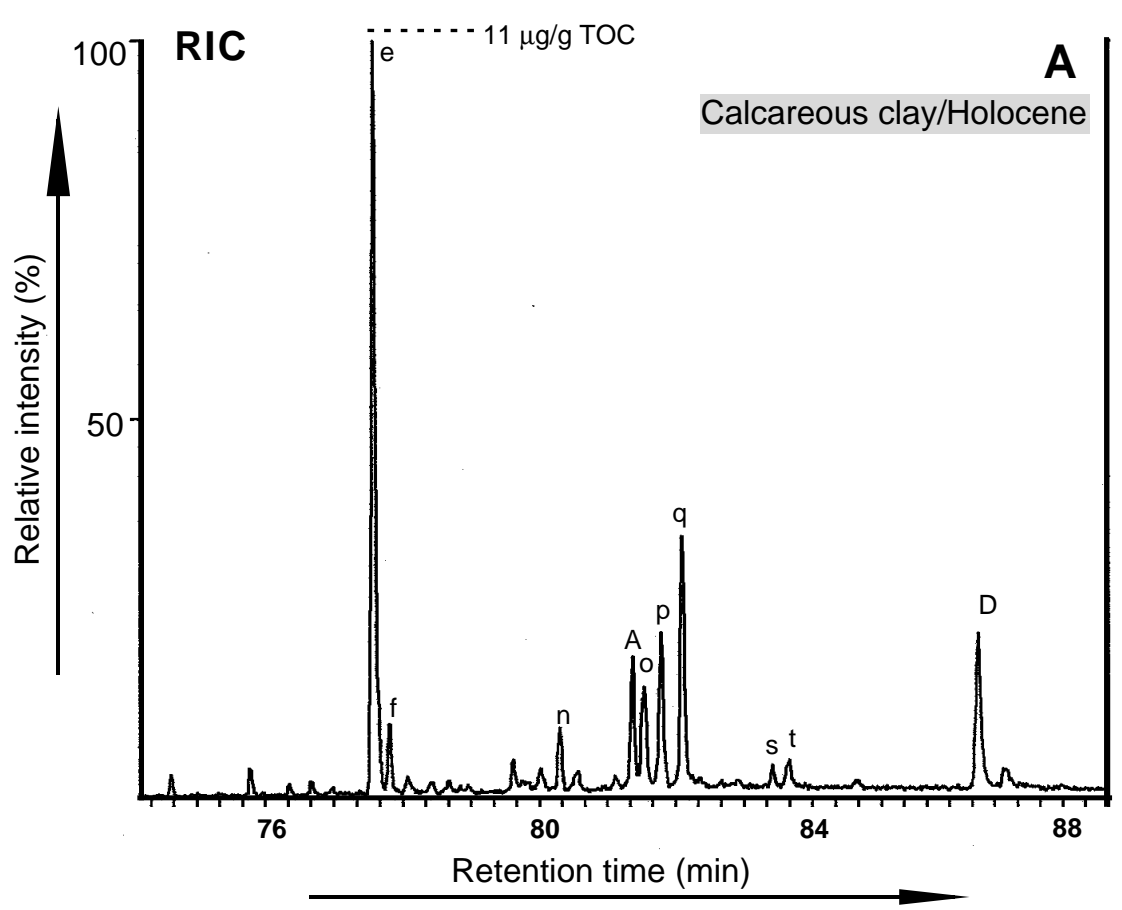

Figure 4. Partial reconstructed ion chromatograms of the sterol fractions of four selected samples from Site 942 showing the elution range of steroid alcohols. The labeled identified compounds are listed in Table 3. $n$-alcohols (numbers) are marked in the chromatogram. A. Sample 155-942C-1H-1, 41-47 cm. B. Sample 155-942A-6H-1, 136-143 cm. C. Sample 155-942A-8H-4, 47-51 cm. D. Sample 155-942A$11 \mathrm{H}-2,5-11 \mathrm{~cm}$.

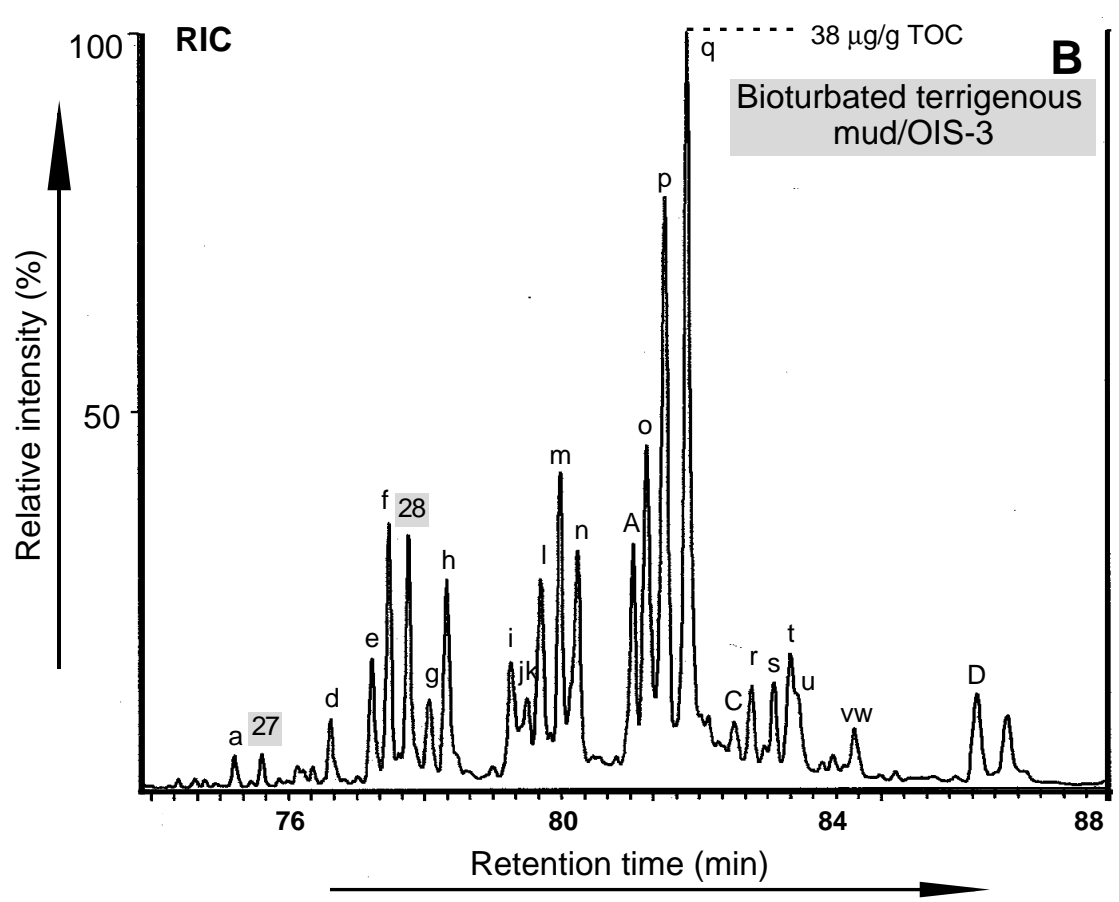

relative distribution of lipids of typical pelagic interglacial sediments where hexadecanoic acid $\left(\mathrm{C}_{16: 1}\right)$ is the major compound in the bitumen. Leaf waxes as source material for the short-chain acids can be excluded by comparison of isotopic data of typical wax components like long-chain $n$-alkanols ( $-35 \%$ o to $-33 \%$ PDB) and $n$-alkanes $(-35 \%$ o to $-33 \%$ PDB; alkanes analyzed by M. Bird, pers. comm., 1995) from the same samples.

\section{Molecular Stratigraphy}

Concentrations of Marine Fatty Acids and Terrigenous Wax Alcohols

As discussed in the previous section, the relative distribution of marine and terrestrial lipid markers appears to correspond to litholog- 

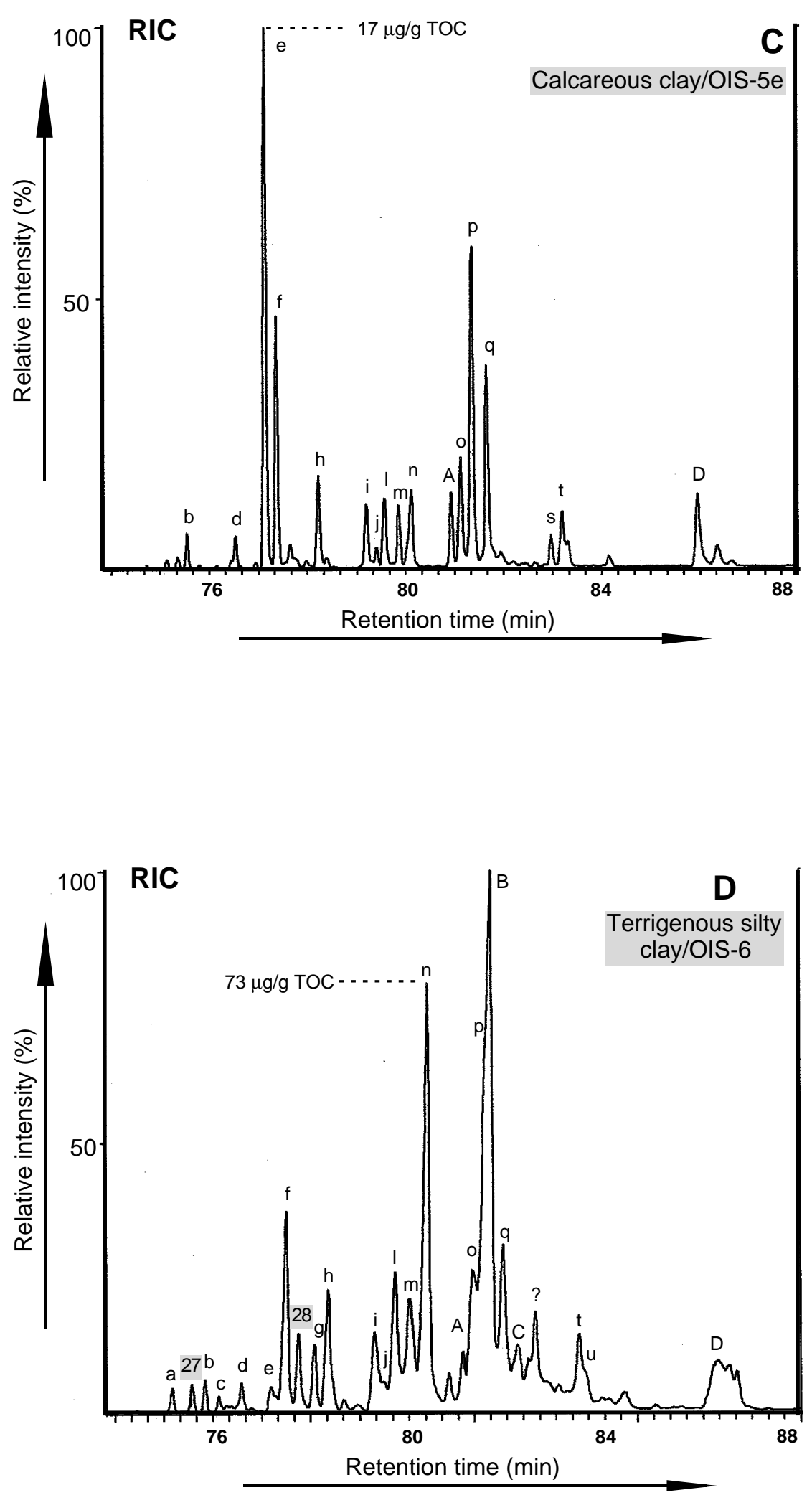

Figure 4 (continued).

ic characteristics. Qualitative differences in lipid distributions appear to be of minor importance. In rapidly accumulated terrigenous muds, the concentrations of marine lipids (e.g., marine fatty acids [MFA = $\left.\left\{\mathrm{C}_{16: 1}, \mathrm{C}_{16: 0}, \mathrm{C}_{18: 1}, \mathrm{C}_{18: 0}\right\}\right]$ ), selected sterols like dinosterol and brassicasterol) are low in relation to terrestrial lipid concentrations (in particular terrigenous wax alcohols [TWA]), whereas the situation in highstand calcareous clays is just the opposite. The relative distributions of MFA and TWA should be closely linked in a certain way to the degree of dilution of autochthonous sediments by Amazon River derived turbidites, and, thus, to sediment accumulation. Such a rough estimate of sediment supply in the Amazon Fan molecular parameters might be useful for the reconstruction of channel growth process- 
Table 3. Steroid and triterpenoid alcohols identified in selected samples together with source assignments.

\begin{tabular}{|c|c|c|}
\hline Symbol & Compound & $\begin{array}{c}\text { Major biological } \\
\text { sources }\end{array}$ \\
\hline a & $5 \beta(\mathrm{H})$-cholestan-3 $\beta$-ol & $\begin{array}{r}\text { Reduction of } \\
\text { cholesterol }\end{array}$ \\
\hline $\mathrm{b}$ & $5 \beta(\mathrm{H})$-cholestan- $3 \alpha$-ol & $\begin{array}{l}\text { Ubiquitous, } \\
\text { marine }\end{array}$ \\
\hline $\mathrm{c}$ & cholesta-5, 22(E)-dien-3 $\beta$-ol & $\begin{array}{l}\text { Ubiquitous, } \\
\text { marine }\end{array}$ \\
\hline $\mathrm{d}$ & $5 \alpha(\mathrm{H})$-cholest-22(E)-en-3 $\beta$-ol & $\begin{array}{l}\text { Ubiquitous, } \\
\text { marine }\end{array}$ \\
\hline $\mathrm{e}$ & cholest-5-en-3 $\beta$-ol & $\begin{array}{l}\text { Ubiquitous, } \\
\text { marine }\end{array}$ \\
\hline f & 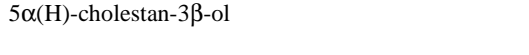 & $\begin{array}{r}\text { Reduction of } \\
\text { cholesterol }\end{array}$ \\
\hline g & 24-methylcholesta-5, 22-dien-3 $\beta$-ol (brassicasterol) & Diatoms \\
\hline $\mathrm{h}$ & 24 -methyl- $5 \alpha(\mathrm{H})$-cholest-22(E)-en-3 $\beta$-ol & Marine plankton \\
\hline $\mathrm{i}$ & Unknown $\mathrm{C}_{27}$-cholestenone & \\
\hline $\mathrm{j}$ & 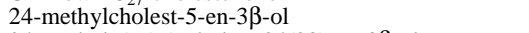 & Marine plankton \\
\hline $\mathrm{k}$ & 24-methyl-5 $\alpha(\mathrm{H})$-cholest-24(28)-en-3 $\beta$-ol & Diatoms \\
\hline 1 & 24 -methyl- $5 \alpha(\mathrm{H})$-cholestan-3 $\beta$-ol & Marine plankton \\
\hline $\mathrm{m}$ & 24-ethylcholesta-5,22(E)-dien-3 $\beta$-ol & Higher land plants \\
\hline $\mathrm{n}$ & 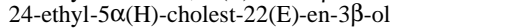 & Higher land plants \\
\hline A & taraxerol & Higher land plants \\
\hline o & 24-ethylcholest-5-en-3 $\beta$-ol & Higher land plants \\
\hline $\mathrm{p}$ & 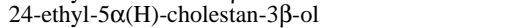 & Higher land plants \\
\hline B & $\beta$-amyrin & Higher land plants \\
\hline $\mathrm{q}$ & $4 \alpha, 23,24$-trimethylcholest-22-en-3 $\beta$-ol (dinosterol) & Dinoflagellates \\
\hline $\mathrm{C}$ & $\alpha$-amyrin & Higher land plants \\
\hline $\mathrm{r}$ & 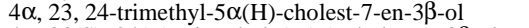 & Dinoflagellates \\
\hline $\mathrm{s}$ & $4 \alpha, 23(\mathrm{~S}), 24(\mathrm{R})$-trimethyl- $5 \alpha(\mathrm{H})$-cholestan-3 $\beta$-ol & Dinoflagellates \\
\hline $\mathrm{t}$ & $4 \alpha, 23(\mathrm{R}), 24(\mathrm{R})$-trimethyl- $5 \alpha(\mathrm{H})$-cholestan- $3 \beta$-ol & Dinoflagellates \\
\hline $\mathrm{u}$ & Unknown $\mathrm{C}_{29}$-stenone & \\
\hline $\mathrm{v}$ & $\mathrm{C}_{30}$ 4-methylstenol + & \\
\hline $\mathrm{w}$ & $5 \alpha$-gorgostanol & \\
\hline $\mathrm{D}$ & n-triacontan-1-ol-17-one? & Marine algae? \\
\hline
\end{tabular}

Note: Selected samples and symbols as in Figures 4 and 5 .

es and could assist in closing gaps in chronology due to the low abundance of fossil foraminifers in Amazon Fan sediments.

Molecular stratigraphic studies, using wax components like $n$-alkanes and/or wax alcohols, are well known from the literature (e.g., Poynter, 1989; Prahl et al., 1994). The ratio of the major wax alcohols over the sum of major wax alkanes and alcohols was previously introduced as the Higher Plant Alcohol (HPA) index by Poynter (1989) as an indicator for chemical degradation of aeolian wax components. Due to the higher reactivity of $n$-alcohols in relation to $n$-alkanes, the HPA index in that study decreased significantly with water depth. However, HPA values greater than 0.6 were assigned to turbiditic deposition.

In Amazon Fan sediments, $n$-alcohols and $n$-alkanes appear to be derived from identical sources as indicated by a more or less constant ratio of these two biomarker groups. The ratio of the major $n$-alcohols (in this case $n-\mathrm{C}_{26}$ and $n-\mathrm{C}_{28}$ ) over the sum of the major $n$-alcohols and the major $n$-alkanes $\left(n-\mathrm{C}_{29}\right.$ and $n$ - $\left.\mathrm{C}_{31}\right)$ is relatively uniform in all samples analyzed. Due to the high concentrations of wax alcohols in samples composed of terrigenous silty clays, these biomarkers are well-suited for molecular stratigraphic investigations. In our study, HPA values (Poynter, 1989) at Sites 940 and 942 range from 0.59 to 0.75 , with an average of $0.68(n=41)$. Samples from Site 940 display quite uniform HPA values, ranging from 0.64 to 0.69 , and an average of $0.67(n=18)$, whereas the average in Site 942 samples is 0.7. According to Poynter (1989), these values are typical for a turbiditic deposition. Differences in the variability are probably related to different sediment transport mechanisms at both sites.

As an alternative approach of accumulation-related molecular stratigraphy, we have determined MFA and TWA concentrations and the resulting TDR' (as defined in the "Analytical Methods" section) for two sets of samples from Sites 940 and 942. The deepest sediments from Site 942 are dated back to Stage 6; therefore, this site is suitable for testing our approach. From a different point of view, Site 940 is of particular interest because most of the sediment sequence was deposited during Stage 2 (Schneider et al, this volume; Flood,
Piper, Klaus, et al., 1995). This potentially allows the investigation of short-term fluctuations in the degree of terrigenous dilution that may have been caused by channel growth processes and paleo-discharge events.

In Figure 6, the concentrations of TWA, MFA, and the TDR' for a set of samples from Site 942 are plotted against depth. The results are listed in Table 4. Terrigenous wax alcohols (Fig. 6A) display a wide range of concentrations from 73 to $2404 \mu \mathrm{g} / \mathrm{g}$ TOC. Lowest concentrations occur in sediments deposited during the Holocene (Sample 155-942C-1H-1, 41-47 cm; $73 \mu \mathrm{g} / \mathrm{g}$ TOC) and Eemian sealevel maxima (Sample 155-942A-8H-4, 47-51 cm; $214 \mu \mathrm{g} / \mathrm{g}$ TOC), when sediments from the Amazon River to the deep ocean were cut off by the wide shelf. TWA concentrations strikingly distinguish sediments deposited during oxygen isotopic Stages 1 to 5 from channel levee sediments of oxygen isotopic Stage 6. Terrigenous muds from Stage 6 are characterized by TWA concentrations exceeding those of hemipelagic muds from Stages 2 through 5 by a factor of $\sim 3$.

Concentrations of MFA (Fig. 6B) are less variable with values ranging from 58 to $668 \mu \mathrm{g} / \mathrm{g}$ TOC, with most values between 100 and $250 \mu \mathrm{g} / \mathrm{g}$ TOC. Interglacial calcareous clays display relatively high concentrations of $284 \mu \mathrm{g} / \mathrm{g}$ TOC in the Holocene sample (155-942C$1 \mathrm{H}-1,41-47 \mathrm{~cm})$ and $555 \mu \mathrm{g} / \mathrm{g}$ TOC in the Eemian sample (155$942 \mathrm{~A}-8 \mathrm{H}-4,47-51 \mathrm{~cm})$. The maximum concentration of $668 \mu \mathrm{g} / \mathrm{g}$ TOC occurs in a sample of hemipelagic mud (155-942A-1H-2, 6-7 $\mathrm{cm})$ at the transition from Stage 2 to the Holocene at $1.56 \mathrm{mbsf}$. In contrast to the TWA concentrations, there is no evidence for characteristic differences of MFA concentrations between hemipelagic muds of Stages 2 through 5 and those of rapidly accumulated terrigenous channel-levee sediments of Stage 6. This fact supports the hypothesis that the preservation of marine lipids is enhanced by rapid burial and the accompanying increasing supply of mineral surface area, leading to the increased protection of labile organic matter by sorptive interactions.

The standardized TDR' (Fig. 6C) is low in highstand calcareous clays of both the Holocene and Eemian interglacials. In hemipelagic muds from Stages 2 through 4, TDR' values are relatively uniform, exceeding the Holocene mean by a factor of $\sim 10-20$. One sample $(155-942 \mathrm{~A}-4 \mathrm{H}-3,69-70 \mathrm{~cm})$ at $26.28 \mathrm{mbsf}$ is characterized by a TDR' value of 47.8 , which is notably affected by a sandy turbidite. In Stage 6, the TDR' is high and increases steadily downhole to a maximum value of 136.6 at a depth of 107.58 mbsf. Below that depth, the TDR' $^{\prime}$ is variable, ranging between 36.7 and 108.7.

Regarding the TDR' as indicator, which reflects the degree of dilution of an autochthonous signal by Amazon River sediments, our data suggest that gradual transgression at the transition from Stage 6 to the Eemian interglacial has led to a continuous decrease of sediment accumulation and a subsequent deactivation of the related channel levee system. The variability of TDR' in levee muds from Stage 6 indicates significant changes in the supply of terrigenous sediments during the formation of channel levee systems. These changes may have been caused by channel growth processes like bifurcation of channel levees or, less likely, by paleodischarge events of the Amazon River.

MFA and TWA concentrations were determined in a set of 19 samples from Hole 940A, representing an expanded sedimentary section of a channel levee. TWA concentrations (Fig. 7A) are low in the Holocene sample (155-940A-1H-1, 11-12 cm), with a value of 107 $\mu \mathrm{g} / \mathrm{g}$ TOC, and an increase to $1393 \mu \mathrm{g} / \mathrm{g}$ TOC at $1.69 \mathrm{mbsf}$. Below that depth, TWA concentrations are fairly constant with values between $1250 \mu \mathrm{g} / \mathrm{g}$ TOC and $1553 \mu \mathrm{g} / \mathrm{g}$ TOC and a slight increase with depth. Sediments below $126.71 \mathrm{mbsf}$ are characterized by a greater variability of TWA concentrations and a continuing trend of downhole increase. The maximum concentration of $2227 \mu \mathrm{g} / \mathrm{g}$ TOC occurs in the deepest sample analyzed (155-940A-27X-4, 67-73 cm) at 244.20 mbsf.

MFA concentrations (Fig. 7B) are highest in the two most shallow samples from Hole 940 with $693 \mu \mathrm{g} / \mathrm{g}$ TOC at $0.11 \mathrm{mbsf}$ and $470 \mu \mathrm{g} /$ $\mathrm{g}$ TOC at $1.69 \mathrm{mbsf}$. Below that depth, MFA concentrations range be- 


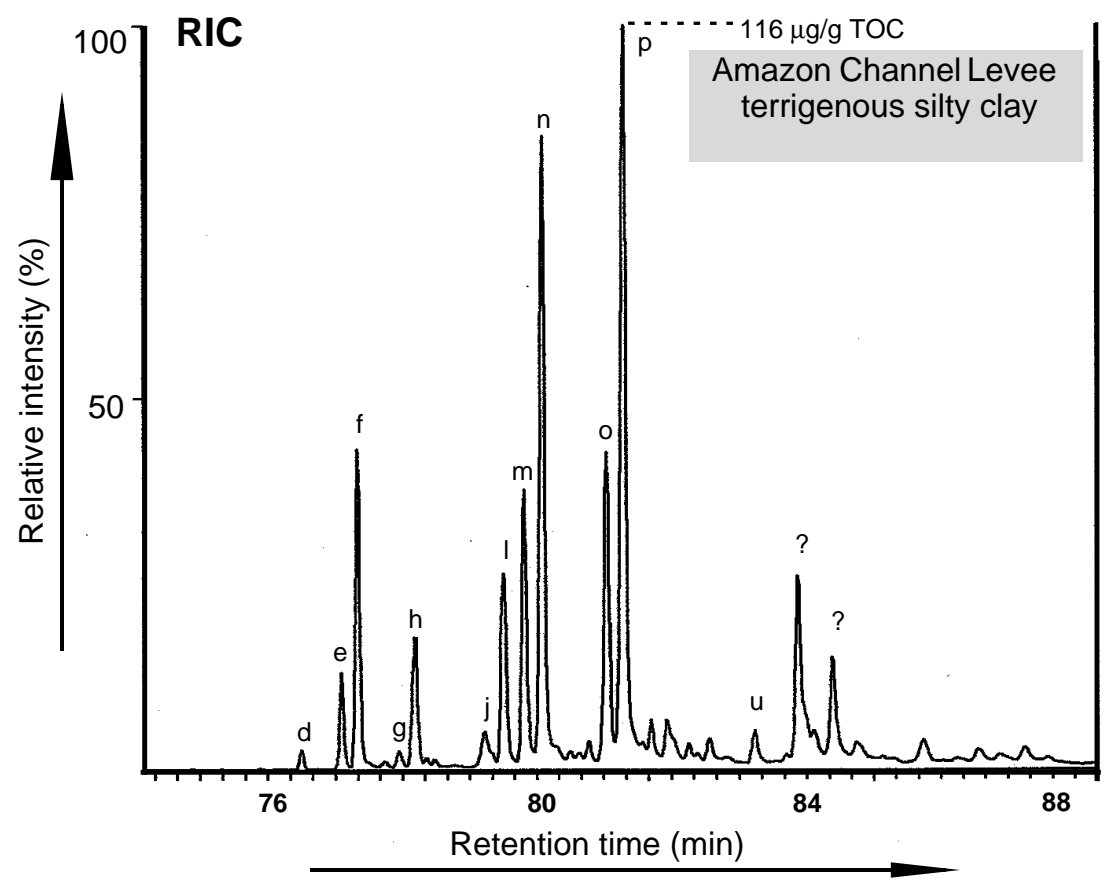

Figure 5. Partial reconstructed ion chromatogram of the sterol fraction of a selected sample $(155-940 \mathrm{~A}-5 \mathrm{H}-$ $5,50-56 \mathrm{~cm}$ ) from Site 940 , showing the elution range of steroid alcohols. The labeled identified compounds are listed in Table 3. tween $51 \mu \mathrm{g} / \mathrm{g}$ TOC and $309 \mu \mathrm{g} / \mathrm{g}$ TOC. Similar to the TWA profile, the MFA profile of Hole 940A exhibits variations, especially in the deeper part of the sedimentary sequence. In that section, MFA concentrations show a pronounced negative correlation with TWA concentrations.

The resulting TDR' (Fig. 7C) values increase from a minimum of 0.6 in the Holocene sample at 0.11 mbsf $(155-940 \mathrm{~A}-1 \mathrm{H}-1,11-12$ $\mathrm{cm})$ to 52.3 at $7.56 \mathrm{mbsf}$. In the interval from $54.33 \mathrm{mbsf}$ to 92.33 mbsf, TDR' values range from 30.4 to 105.4 , with a steady downhole increase. The deeper half of Hole 940A shows marked variations in TDR' values, ranging from 25.9 to 170.4 . Three distinct maxima occur at $137.70 \mathrm{mbsf}\left(\mathrm{TDR}^{\prime}=149.6\right), 195.53 \mathrm{mbsf}\left(\mathrm{TDR}^{\prime}=170.4\right)$, and $244.20 \mathrm{mbsf}\left(\mathrm{TDR}^{\prime}=121.9\right)$. Distinct $\mathrm{TDR}^{\prime}$ minima occur at 147.35 mbsf $\left(\mathrm{TDR}^{\prime}=21.5\right), 165.12 \mathrm{mbsf}\left(\mathrm{TDR}^{\prime}=25.9\right)$, and $205.19 \mathrm{mbsf}$ $\left(\mathrm{TDR}^{\prime}=21.2\right)$.

The two stronger maxima at 195.53 and 137.70 mbsf most probably are related to the beginning of levee growth cycles, as indicated by the seismic profile (Pirmez and Flood, 1995). The maximum at 195.53 mbsf coincides well with a seismic reflection that marks the change from a prograding to an aggrading levee system (C. Pirmez, pers. comm., 1995). The maximum at $137.70 \mathrm{mbsf}$ correlates with the top of the Aqua Channel-levee System, which is estimated at 130140 mbsf (C. Pirmez, pers. comm., 1995).

The two minima in the TDR' profile at 147.35 and $165.12 \mathrm{mbsf}$ are most likely related to intervals of more slowly accumulated sediments. The sample at 165.12 mbsf $(155-940 \mathrm{~A}-19 \mathrm{X}-3,22-23 \mathrm{~cm})$ is from an interval of low to moderate bioturbation, suggesting a moderate sediment accumulation rate that agrees with the determined TDR' value. The sample at 147.35 mbsf (155-940A-17X-4, 25-26 $\mathrm{cm}$ ) was taken from a resedimented clast, and so the TDR' value may not be related to a period of reduced sediment accumulation at this depth level. The interval from 92.33 mbsf to 54.33 mbsf, characterized by upward decreasing TDR' values ranging from 105.4 to 36.9 , is composed of slightly to moderately bioturbated sediments (Flood, Piper, Klaus, et al., 1995), indicating moderate sediment accumulation rates. The upward decrease of TDR' values is likely to be related to the cutoff of Amazon River sediment transport to the Amazon Fan caused by the sea-level rise at the transition to the Holocene.

In summary, preliminary data indicate that the TDR can be a useful tool for monitoring downhole variations of sedimentation patterns in the sedimentary environment of the Amazon Fan. Based on TDR, pelagic calcareous clays, as well as hemipelagic sediments, can clearly be identified by low and moderate values. Moreover, sedimentary events, related to the periodically occurring formation of acoustically recognizable channel-levee systems, appear to be identifiable by the TDR. Further increase of resolution may reveal even more detailed information concerning variations of sedimentation patterns with time in such a channel-levee growth cycle.

Further information is needed concerning the effect of sediment grain size on TDR'. It is possible that a coarser sediment matrix favors the selective preservation of terrigenous organic matter due to a reduced sorptive protection of the more labile marine organic matter (Keil et al., 1994; Hedges and Keil, 1995) and/or by increased diffusion of oxygen into coarser grained sediments.

Other approaches to record changes in the relative proportion of marine vs. terrigenous organic matter, like the determination of $\delta^{13} \mathrm{C}$ values of bulk organic matter, give very similar results concerning the distinction between pelagic, hemipelagic, and terrigenous sediments in the Amazon Fan environment (Schneider et al., this volume). In contrast to the TDR approach, stable carbon isotopes do not indicate changes in the degree of dilution in terrigenous channellevee sediments. The determination of $\mathrm{C} / \mathrm{N}$ ratios failed to exhibit changes of the relative proportion of marine and terrigenous organic matter. For example, atomic C/N ratios from Site 942, analyzed aboard the JOIDES Resolution, ranged from 5 to 12 (with the exception of one sample with $0.02 \%$ TOC and an atomic $\mathrm{C} / \mathrm{N}$ ratio of 3 ) with slightly lower values in samples with elevated carbonate contents, and, thus, indicated a significant contribution of inorganic nitrogen rendering the data insignificant (Flood, Piper, Klaus, et al., 1995). Atomic $\mathrm{C} / \mathrm{N}$ ratios in hemipelagic and terrigenous sediments from Site 942 were in the same range.

Caution should be taken if the TDR is to be applied to environments other than deep-sea fans of major rivers, where the supply of terrigenous sediment exceeds autochthonous sedimentation by a few orders of magnitude. In addition, problems may arise in areas of high marine productivity, because changes in productivity may significantly affect the marine signal preserved in the sediments.

\section{CONCLUSIONS}

Late Pleistocene and Holocene sediments drilled in the Amazon Fan contain substantial amounts of organic carbon of mainly terrige- 


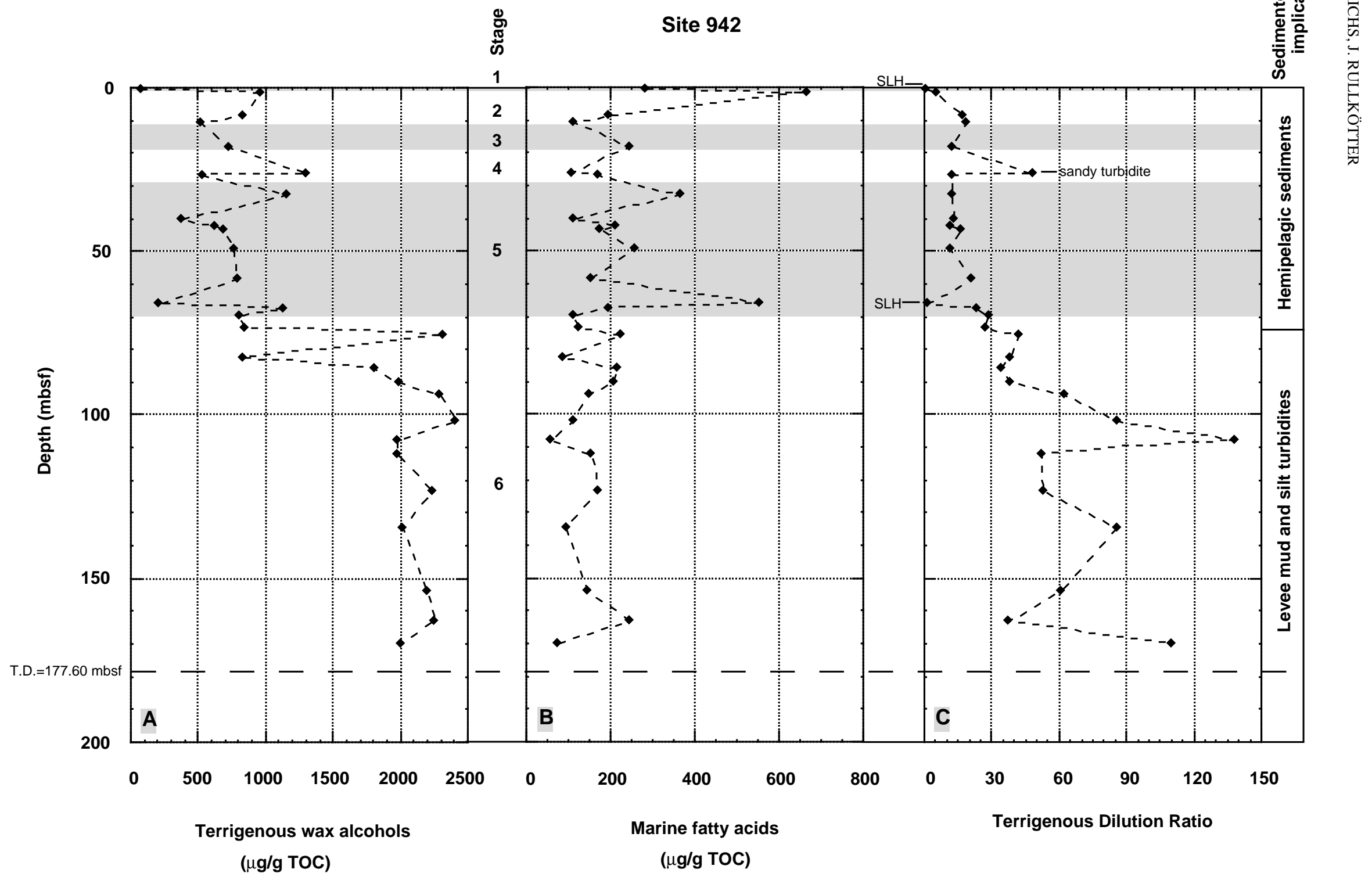

Figure 6. Concentrations of (A) terrigenous wax alcohols, (B) marine fatty acids, and (C) Terrigenous Dilution Ratio vs. depth in sediments from Site 942 . Interglacials (chronology by Showers et al., this volume) are shaded in gray.SLH = sea-level highstand. 
Table 4. Concentrations of terrigenous wax alcohols, marine fatty acids, and the resulting standardized Terrigenous Dilution Ratio in sediments from Sites 940, 942, and 943.

\begin{tabular}{|c|c|c|c|c|c|c|}
\hline $\begin{array}{l}\text { Core, section, } \\
\text { interval }(\mathrm{cm})\end{array}$ & $\begin{array}{l}\text { Depth } \\
\text { (mbsf) }\end{array}$ & $\begin{array}{l}\text { TWA } \\
(\mu \mathrm{g} / \mathrm{g})\end{array}$ & $\begin{array}{c}\text { TWA } \\
(\mu \mathrm{g} / \mathrm{g} \text { TOC })\end{array}$ & $\begin{array}{l}\text { MFA } \\
(\mu \mathrm{g} / \mathrm{g})\end{array}$ & $\begin{array}{c}\text { MFA } \\
(\mu \mathrm{g} / \mathrm{g} \text { TOC })\end{array}$ & $\mathrm{TDR}^{\prime}$ \\
\hline \multicolumn{7}{|l|}{ 155-940A- } \\
\hline $1 \mathrm{H}-1,11-12$ & 0.11 & 0.5 & 107 & 3.0 & 693 & 0.60 \\
\hline $1 \mathrm{H}-2,20-25$ & 1.69 & 11.6 & 1393 & 3.9 & 470 & 11.9 \\
\hline $2 \mathrm{H}-4,41-47$ & 7.56 & 11.6 & 1250 & 0.9 & 97 & 52.3 \\
\hline $3 \mathrm{H}-4,45-50$ & 17.27 & 11.3 & 1333 & 0.9 & 106 & 51.2 \\
\hline $5 \mathrm{H}-5,50-56$ & 36.34 & 12.6 & 1330 & 1.7 & 178 & 30.4 \\
\hline $6 \mathrm{H}-4,102-108$ & 45.84 & 11.8 & 1322 & 0.9 & 104 & 51.5 \\
\hline $7 \mathrm{H}-4,54-61$ & 54.33 & 15.2 & 1506 & 1.7 & 165 & 36.9 \\
\hline $8 \mathrm{H}-6,50-57$ & 67.71 & 13.1 & 1486 & 1.0 & 116 & 51.9 \\
\hline $10 X-4,48-55$ & 81.94 & 16.3 & 1553 & 1.1 & 100 & 63.1 \\
\hline $11 X-6,34-42$ & 92.53 & 15.3 & 1518 & 0.6 & 58 & 105.4 \\
\hline $15 X-3,40-45$ & 126.71 & 13.5 & 2041 & 1.2 & 178 & 46.5 \\
\hline $16 X-4,53-59$ & 137.70 & 15.6 & 1905 & 0.4 & 52 & 149.6 \\
\hline $17 X-4,25-26$ & 147.35 & 12.2 & 1631 & 2.3 & 309 & 21.5 \\
\hline $17 X-4,47-48$ & 147.57 & 12.4 & 1454 & 1.9 & 220 & 26.9 \\
\hline $18 X-4,37-43$ & 157.02 & 19.3 & 2079 & 1.1 & 114 & 73.8 \\
\hline $19 \mathrm{X}-3,22-23$ & 165.12 & 14.8 & 1492 & 2.3 & 234 & 25.9 \\
\hline $22 \mathrm{X}-4,25-31$ & 195.53 & 16.8 & 2159 & 0.4 & 51 & 170.4 \\
\hline $23 X-4,66-67$ & 205.19 & 10.7 & 1487 & 2.1 & 287 & 21.2 \\
\hline $27 X-4,67-73$ & 244.20 & 18.0 & 2227 & 0.6 & 74 & 121.9 \\
\hline \multicolumn{7}{|l|}{ 155-942A- } \\
\hline $1 \mathrm{H}-2,6-7$ & 1.56 & 7.8 & 960 & 5.4 & 668 & 5.7 \\
\hline $2 \mathrm{H}-4,37-38$ & 8.67 & 6.5 & 837 & 1.5 & 196 & 17.1 \\
\hline $2 \mathrm{H}-5,80-86$ & 10.63 & 4.0 & 526 & 0.9 & 112 & 18.8 \\
\hline $3 \mathrm{H}-4,36-37$ & 18.04 & 4.9 & 730 & 1.6 & 244 & 12.0 \\
\hline $4 \mathrm{H}-3,69-70$ & 26.28 & 9.4 & 1302 & 0.8 & 109 & 47.8 \\
\hline $4 \mathrm{H}-4,3-4$ & 27.07 & 3.0 & 538 & 0.9 & 171 & 12.6 \\
\hline $5 \mathrm{H}-1,47-49$ & 32.76 & 5.7 & 1158 & 1.8 & 367 & 12.6 \\
\hline $5 \mathrm{H}-7,46-47$ & 40.44 & 2.4 & 376 & 0.7 & 113 & 13.3 \\
\hline $6 \mathrm{H}-1,46-47$ & 42.26 & 2.3 & 629 & 0.8 & 214 & 11.8 \\
\hline $6 \mathrm{H}-1,136-143$ & 43.20 & 3.0 & 696 & 0.8 & 176 & 15.8 \\
\hline $6 \mathrm{H}-5,140-141$ & 49.13 & 2.9 & 763 & 1.0 & 259 & 11.8 \\
\hline $7 \mathrm{H}-6,5-6$ & 58.65 & 3.5 & 790 & 0.7 & 153 & 20.7 \\
\hline $8 \mathrm{H}-4,47-51$ & 65.79 & 0.7 & 214 & 1.8 & 555 & 1.5 \\
\hline $8 \mathrm{H}-5,55-56$ & 67.35 & 6.4 & 1131 & 1.1 & 194 & 23.3 \\
\hline $8 \mathrm{H}-6,119-120$ & 69.49 & 6.3 & 812 & 0.9 & 114 & 28.5 \\
\hline $9 \mathrm{H}-4,79-80$ & 73.46 & 6.8 & 849 & 1.0 & 126 & 27.0 \\
\hline $9 \mathrm{H}-7,12-13$ & 75.55 & 19.1 & 2324 & 1.8 & 223 & 41.7 \\
\hline $10 \mathrm{H}-2,124-125$ & 82.33 & 5.5 & 839 & 0.6 & 88 & 38.1 \\
\hline $10 \mathrm{H}-5,66-67$ & 85.96 & 14.3 & 1805 & 1.7 & 215 & 33.6 \\
\hline $11 \mathrm{H}-2,5-11$ & 90.07 & 18.6 & 1995 & 2.0 & 210 & 38.0 \\
\hline $11 \mathrm{H}-5,4-5$ & 93.97 & 21.3 & 2290 & 1.4 & 148 & 61.9 \\
\hline $12 \mathrm{H}-3,51-52$ & 102.03 & 22.4 & 2404 & 1.1 & 113 & 85.1 \\
\hline $13 X-3,58-59$ & 107.58 & 20.0 & 1981 & 0.6 & 58 & 136.6 \\
\hline $14 X-2,39-40$ & 111.99 & 20.4 & 1979 & 1.6 & 154 & 51.4 \\
\hline $15 X-3,47-48$ & 123.17 & 22.6 & 2237 & 1.7 & 171 & 52.3 \\
\hline $16 X-4,76-77$ & 134.56 & 20.4 & 2017 & 1.0 & 94 & 85.8 \\
\hline $18 X-4,53-54$ & 153.63 & 23.8 & 2201 & 1.6 & 147 & 59.9 \\
\hline $19 X-4,36-37$ & 163.16 & 23.7 & 2259 & 2.6 & 246 & 36.7 \\
\hline $20 X-2,42-43$ & 169.82 & 21.3 & 2011 & 0.8 & 74 & 108.7 \\
\hline \multicolumn{7}{|l|}{$155-942 C-$} \\
\hline $1 \mathrm{H}-1,41-47$ & 0.44 & 0.28 & 73 & 1.1 & 284 & 1.04 \\
\hline \multicolumn{7}{|l|}{ 155-943A- } \\
\hline $1 \mathrm{H}-1,5-6$ & 0.05 & 0.24 & 64 & 0.8 & 205 & 1.27 \\
\hline $1 \mathrm{H}-1,92-93$ & 0.92 & 0.20 & 75 & 0.8 & 289 & 1.08 \\
\hline
\end{tabular}

Notes: TWA $=$ terrigenous wax alcohols; $\mathrm{MFA}=$ marine fatty acids $; \mathrm{TDR}^{\prime}=$ Terrigenous Dilution Ratio. TOC $=$ total organic carbon. Samples used for the calculation of the Holocene average TDR are framed.

nous origin. Only highstand calcareous clays with low organic carbon contents show a stronger marine signature. The organic material in these clays is assumed to mainly represent the oxidized refractory residue of autochthonous organic matter that has survived continuous ventilation under oxic bottom water conditions and low burial rates.

Polar lipid distributions distinguish different sedimentary facies drilled in the Amazon Fan. The bitumen composition of terrigenous channel-levee sediments, commonly containing $\sim 1 \%$ TOC, is fairly complex. Higher land plant wax components, like long-chain $n$-alcohols, are the predominant compound class in the bitumen of all analyzed sediments of terrigenous origin. In rapidly accumulated channel-levee sediments, this group reaches maximum concentrations of $2400 \mu \mathrm{g} / \mathrm{g}$ TOC. Other terrigenous biomarkers like $\alpha$-amyrin, friedelan-3-one, and related triterpenoid alcohols and ketones, as well as higher land plant-derived sterols, also represent a substantial portion of the soluble organic matter in channel levee sediments. Bacterial biomarkers with hopanoid structures can be identified in Amazon River derived sediments. Their presence is most likely related to both bacterial activities in soils from the hinterland as well as to autochthonous bacterial degradation of organic matter.

The bitumen of pelagic sediments, deposited during periods of sea-level maxima, are characterized by simpler molecular compositions with the ubiquitously occurring $n$-hexadecanoic acid as the major compound. This compound and related short-chain fatty acids most likely were contributed to the sediment by autochthonous planktonic production under a dominance of both pelagic and terrigenous supply as confirmed by compound-specific isoptope analyses of selected samples from Site 940. In addition, other plankton-derived biomarkers like dinosterol and brassicasterol are present in substantial amounts in both pelagic and hemipelagic sediments. With increasing sediment accumulation rates, the marine signals become diluted by terrigenous biomarkers supplied by the turbidity currents of the Amazon River.

We used this observation to define a TDR', which is the ratio of the sum of terrigenous wax alcohols over the sum of the four major marine fatty acids. The TDR' spans more than two orders of magnitude (total range of TDR $=0.6-170.4$ ) in more than 50 samples analyzed. We suggest that these variations of the TDR' reflect differences in sedimentation pattern. In sediments from Site 942, the TDR' clearly distinguishes pelagic, hemipelagic, and channel-levee sediments. Moreover, in channel-levee sediments like those from Site 940, the TDR' appears to reflect changes in sedimentation patterns that are associated with the formation of acoustically incoherent stages of the levee system.

\section{ACKNOWLEDGMENTS}

We are indebted to Drs. Barbara Scholz-Böttcher and Michael Böttcher (ICBM) for support in GC-MS and GC-irm-MS analysis. We are grateful to Dr. C. Pirmez, Dr. R. Schneider, and B. Schlünz for helpful discussions. Critical comments by Dr. R.D. Flood, Dr. F.G. Prahl, and an anonymous reviewer were highly appreciated and greatly improved the quality of the manuscript. We thank Dr. M. Bird for providing us with stable carbon isotopic data from $n$-alkanes. The study was financially supported by the Deutsche Forschungsgemeinschaft (DFG), Grant \# Ru 458/8.

\section{REFERENCES}

Albro, P.W., 1976. Bacterial waxes. In Kollatukudy, P.E. (Eds.), Chemistry and Biochemistry of Natural Waxes: New York (Elsevier), 419-445.

Boon, J.J., Rijpstra, W.I.C., de Lange, F., de Leeuw, J.W., Yoshioka, M., and Shimizu, Y., 1979. Black sea sterol-a molecular fossil for dinoflagellate blooms. Nature, 277:125-127.

Bouma, A.H., Normark, W.R., and Barnes, N.E., 1985. Submarine Fans and Related Turbidite Systems: New York (Springer).

Brassell, S.C., 1980. The lipids of deep sea sediments: their origin and fate in the Japan Trench [Ph.D. dissert.]. Univ. Bristol.

Brassell, S.C., and Eglinton, G., 1981. Biogeochemical significance of a novel sedimentary $C_{27}$ stanol. Nature, 290:579-582.

Damuth, J.E., and Kumar, N., 1975. Amazon Cone: morphology, sediments, age, and growth pattern. Geol. Soc. Am. Bull., 86:863-878.

Damuth, J.E., Flood, R.D., Knowsmann, R.O., Belderson, R.H., Gorini, M.A., 1988. Anatomy and growth patterns of Amazon deep-sea fan as revealed by long-range side-scan sonar (GLORIA) and high-resolution seismic studies. AAPG Bull., 72:885-911

Dastillung, M., 1976. Lipides de sediments recents [Ph.D. thesis]. Univ. Louis Pasteur, Strasbourg, France.

Dastillung, M., Albrecht, P., and Ourisson, G., 1980. Alcools aliphatiques et polycycliques dans les sédiments: alcools dérivés du hopane et du 3méthylhopane. J. Chem. Res., M:2353-2374.

DeMaster, D.J., and Pope, R.H., 1996. Nutrient dynamics in Amazon shelf waters: results from AmasSeds. Cont. Shelf Res., 16:263-289. 
Eglinton, G., and Hamilton, R.J., 1967. Leaf epicuticular waxes. Science, 156:1322-1335.

Ertel, J.R., Hedges, J.I., Devol, A.H., Richey, J.E., and Riberio, M., 1986. Dissolved humic substances of the Amazon River system. Limnol. Oceanogr, 31:739-754.

Flood, R.D., Piper, D.J.W., and Shipboard Scientific Party, 1995. Introduction. In Flood, R.D., Piper, D.J.W., Klaus, A., et al., Proc. ODP, Init. Repts., 155: College Station, TX (Ocean Drilling Program), 5-16.

Flood, R.D., Piper, D.J.W., Klaus, A., et al., 1995. Proc. ODP, Init. Repts., 155: College Station, TX (Ocean Drilling Program).

Freeman, K., Pancost, R.D., Filley, T.R., and Wakeham, S.G., 1995. Environmental and physiological controls on the $\delta^{13} \mathrm{C}$ of phytoplankton biomarkers: sterols and alkenones from marine waters and sediments. In Grimalt, J.O., Dorronsoro, C. (Eds.), Organic Geochemistry: Developments and Applications to Energy, Climate, Environment and Human History: Donostia-San Sebastian, Spain (A.I.G.O.A.),14-16.

Goñi, M.A., and Eglinton, T.I., 1994. Analysis of kerogens and kerogen precursors by flash pyrolysis in combination with isotope-ratio-monitoring gas chromatography-mass spectrometry (irm-GC-MS). J. High Res. Chromatogr., 17:476-488.

Gramberg, D., Scholz-Böttcher, B.M., and Rullkötter, J., 1995. Column chromatographic separation and characterization of a complex mixture of heterocompounds in the extractable lipids of a phragmites peat. In Grimalt, J.O., Dorronsoro, C. (Eds.), Organic Geochemistry: Developments and Applications to Energy, Climate, Environment and Human History: Donostia-San Sebastian, Spain (A.I.G.O.A.), 174-177.

Hedges, J.I., Clark, W.A., Quay, P.D., Rochey, J.E., Devol, A.H., and Sandos, U.M., 1986. Compositions and fluxes of particulate organic material in the Amazon River. Limnol. Oceanogr., 31:717-738.

Hedges, J.I., and Keil, R.G., 1995. Sedimentary organic matter preservation: an assessment and speculative synthesis. Mar. Chem., 49:81-115.

Hinrichs, K.-U., Rinna, J., and Rullkötter, J., 1995a. Sterol compositions in sediments of the Santa Barbara Basin, California: assessment of their potential for paleoenvironmental reconstructions. In Grimalt, J.O., Dorronsoro, C. (Eds.), Organic Geochemistry: Developments and Applications to Energy, Climate, Environment and Human History: DonostiaSan Sebastian, Spain (A.I.G.O.A.), 244-246.

Hinrichs, K.-U., Rullkötter, J., and Stein, R., 1995b. Preliminary assessment of organic geochemical signals in sediments from Hole 893A, Santa Barbara Basin, offshore California. In Kennett, J.P., Baldauf, J.G., and Lyle, M. (Eds.), Proc. ODP, Sci. Results, 146 (Pt. 2): College Station, TX (Ocean Drilling Program), 201-211.

Keil, R.G., Montluçon, D.B., Prahl, F.G., and Hedges, J.I., 1994. Sorptive preservation of labile organic matter in marine sediments. Nature, 370:549-552.
Manley, P.L., and Flood, R.D., 1988. Cyclic sediment deposition within the Amazon deep-sea fan. AAPG Bull., 72:912-925.

McEvoy, J., 1983. The origin and diagenesis of organic lipids in sediments from the San Miguel Gap [Ph.D. dissert.]. Univ. Bristol.

Pirmez, C., and Flood, R.D., 1995. Morphology and structure of Amazon Channel. In Flood, R.D., Piper, D.J.W., Klaus, A., et al., Proc. ODP, Init. Repts., 155: College Station, TX (Ocean Drilling Program), 23-45.

Poynter, J.G., 1989. Molecular stratigraphy: the recognition of paleoclimatic signals in organic geochemical data. [Ph.D. dissert.]. Univ. of Bristol.

Prahl, F.G., Ertel, J.R., Goni, M.A., Sparrow, M.A., and Eversmeyer, B., 1994. Terrestrial organic carbon contributions to sediments on the Washington margin. Geochim. Cosmochim. Acta, 58:3035-3048.

Prahl, F.G., Hayes, J.M., and Xie, T.-M., 1992. Diploptene: an indicator of terrigenous organic carbon in Washington coastal sediments. Limnol. Oceanogr., 37:1290-1300.

Radke, M., Willsch, H., and Welte, D.H., 1980. Preparative hydrocarbon group type determination by automated medium pressure liquid chromatography. Anal. Chem., 52:406-411.

Rieley, G., Collier, R.J., Jones, D.M., Eglinton, G., Eakin, P.A., and Fallick, A.E., 1991. Sources of sedimentary lipids deduced from stable carbonisotope analyses of individual compounds. Nature, 352:425-427.

Rohmer, M., Dastillung, M., and Ourisson, G., 1980. Hopanoids from $\mathrm{C}_{30}$ to $\mathrm{C}_{35}$ in Recent Muds. Naturwissenschaften, 67:456-458.

Still, W.C., Kahn, M., and Mitra, A., 1978. Rapid chromatographic technique for preparative separations with moderate resolutions. J. Org. Chem., 43:2923-2926.

Venkatesan, M.I., Ruth, E., and Kaplan, I.R., 1990. Triterpenols from sediments of Santa Monica Basin, Southern California Bight, U.S.A. Org. Geochem., 16:1015-1024.

Volkman, J.K., 1986. A review of sterol markers for marine and terrigenous organic matter. Org. Geochem., 9:83-99.

Volkman, J.K., Farrington, J.W., and Gagosian, R.B., 1987. Marine and terrigenous lipids in coastal sediments from the Peru upwelling region at $15^{\circ} \mathrm{S}$ : sterol and triterpene alcohols. Org. Geochem., 11:463-477.

Weete, J.D., 1976. Algal and fungal waxes. In Kollatukudy, P.E. (Eds.), Chemistry and Biochemistry of Natural Waxes: New York (Elsevier), 349-418.

Date of initial receipt: 7 December 1995

Date of acceptance: 12 July 1996

Ms 155SR-238 


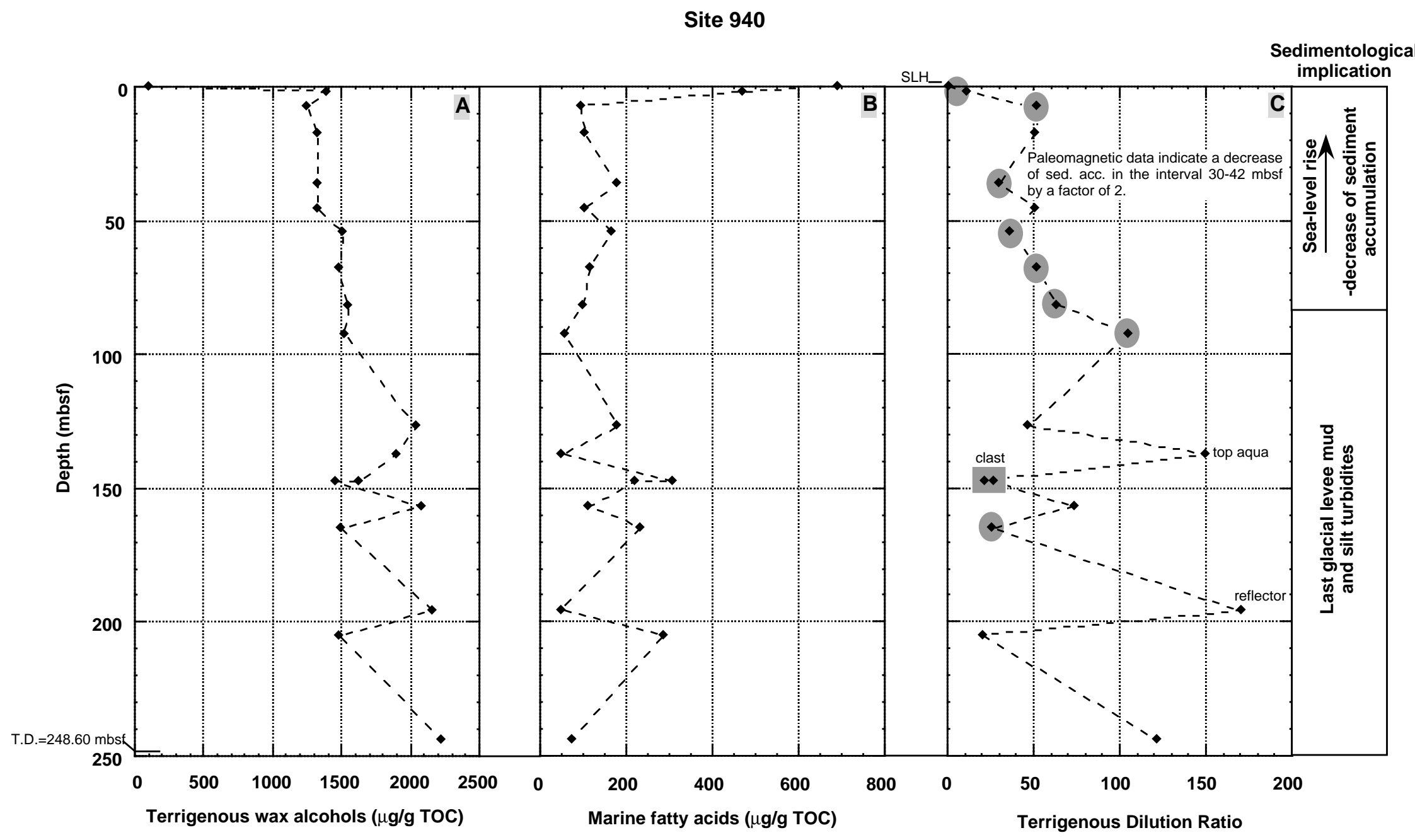

- = bioturbated sediment

Figure 7. Concentrations of (A) terrigenous wax alcohols, (B) marine fatty acids, and (C) Terrigenous Dilution Ratio vs. depth in sediments from Site 940 . SLH $=$ sea-level highstand. 